\title{
IS GIFTED EDUCATION A BRIGHT IDEA? ASSESSING THE IMPACT OF GIFTED AND TALENTED PROGRAMS ON ACHIEVEMENT
}

\author{
Sa A. Bui \\ Steven G. Craig \\ Scott A. Imberman \\ Working Paper 17089 \\ http://www.nber.org/papers/w17089
NATIONAL BUREAU OF ECONOMIC RESEARCH
1050 Massachusetts Avenue
Cambridge, MA 02138

May 2011

We would like to thank Aimee Chin, Dennis Epple, Jason Imbrogno, Chinhui Juhn, Brian Kovak, Jacob Vigdor and seminar participants at APPAM, AEFP, SOLE, Carnegie Mellon University, Georgetown University, University of Houston, and University of Maryland, and the employees of an anonymous school district for all of their guidance and assistance in this project. Financial support from the University of Houston Small Grants program is gratefully appreciated. The views expressed herein are those of the authors and do not necessarily reflect the views of the National Bureau of Economic Research.

NBER working papers are circulated for discussion and comment purposes. They have not been peerreviewed or been subject to the review by the NBER Board of Directors that accompanies official NBER publications.

(C) 2011 by Sa A. Bui, Steven G. Craig, and Scott A. Imberman. All rights reserved. Short sections of text, not to exceed two paragraphs, may be quoted without explicit permission provided that full credit, including $\odot$ notice, is given to the source. 
Is Gifted Education a Bright Idea? Assessing the Impact of Gifted and Talented Programs

on Achievement

Sa A. Bui, Steven G. Craig, and Scott A. Imberman

NBER Working Paper No. 17089

May 2011

JEL No. H75,I2

\begin{abstract}
In this paper we determine how the receipt of gifted and talented (GT) services affects student outcomes. We identify the causal relationship by exploiting a discontinuity in eligibility requirements and find that for students on the margin there is no discernable impact on achievement even though peers improve substantially. We then use randomized lotteries to examine the impact of attending a GT magnet program relative to GT programs in other schools and find that, despite being exposed to higher quality teachers and peers that are one standard deviation higher achieving, only science achievement improves. We argue that these results are consistent with an invidious comparison model of peer effects offsetting other benefits. Evidence of large reductions in course grades and rank relative to peers in both regression discontinuity and lottery models are consistent with this explanation.
\end{abstract}

Sa A. Bui

University of Houston

204 McElhinney Hall

Houston, TX 77204-5019

sabui2@mail.uh.edu

Steven G. Craig

University of Houston

Department of Economics

204 McElhinney Hall

Houston, TX 77204-5019

scraig@uh.edu
Scott A. Imberman

Department of Economics

University of Houston

204 McElhinney Hall

Houston, TX 77204

and NBER

simberman@uh.edu

An online appendix is available at:

http://www.nber.org/data-appendix/w17089 


\section{Introduction}

The pending reauthorization of the No Child Left Behind Act (NCLB) has renewed interest in gifted education, in part due to research suggesting that NCLB may have been less effective at helping high achieving than low achieving students (Neal and Schanzenbach, 2010; Rebeck, 2008). One possible channel for these findings is the shifting of resources from gifted to low-achieving students as the incentives in NLCB are to help the latter and not the former. The opportunity costs of such a resource diversion are difficult to discern, however, because little is known about the effectiveness of gifted and talented (GT) programs for the three million students in the US who are classified as gifted. GT programs might help high achieving students because they group them with other high-achievers, and offer a variety of additional resources including specially trained teachers and a more advanced curriculum. While early research finds that ability grouping is correlated with higher achievement, many of these studies are likely biased due to unobserved characteristics of students, such as motivation, that simultaneously lead students to be successful and to be grouped in high ability classrooms. ${ }^{2}$ Recently, some researchers have tried to address the bias issue in ability grouping, but with mixed results (Argys, Rees and Brewer, 1996; Betts and Shkolnik, 2000; Epple, Newlon and Romano, 2002; Figlio and Page, 2002; Duflo, Dupas and Kremer, forthcoming). Our analysis goes beyond these studies as it focuses on a group of students who are not well studied - high achievers - and the effectiveness of the services provided to them. As such, our work significantly expands our understanding of gifted and talented programs, as we explicitly address their effectiveness using two unique strategies for overcoming bias - a regression discontinuity design embedded within the eligibility requirements and an analysis of lotteries to attend premier GT magnet programs.

\footnotetext{
${ }^{2}$ See Kulik and Kulik (1997) for a review.
} 
Specifically, we utilize the case of a universal GT evaluation in a large urban school district in the Southwest (LUSD) where, since 2007, all fifth grade students have been evaluated to determine eligibility for gifted and talented services starting in sixth grade. Eligibility is identified by two well-defined cutoffs on an index score that is based on achievement tests, a non-verbal ability test, grades, teacher recommendations, and socio-economic status. We exploit these cutoffs to set up a regression discontinuity (RD) design whereby students who score just above the cutoffs are compared to those who score just below. Under certain conditions, for which we provide evidence that this analysis meets, our estimates provide the causal impact of enrolling in a GT program on achievement for students on the margin of eligibility.

The second research strategy we employ uses randomized lotteries that determine admission to two middle schools with over-subscribed magnet GT programs. Conditional on meeting the district-wide GT eligibility requirements and completing an application, students are randomly offered admission to the district's premier magnet schools. This allows us to examine achievement and attendance differences between students who win the lottery and attend the magnet GT schools, and those who lose the lottery and attend other "neighborhood” programs. ${ }^{3}$ We also provide evidence that these premier GT schools generate a more intensive treatment along observable measures than the neighborhood GT programs.

To our knowledge, only Bhatt (2009) specifically studies the effect of GT programs on achievement, although Davis, Engberg, Epple, Sieg and Zimmer (2010) find that higher income parents are more likely to stay in public schools when their children are eligible for GT programs. While Bhatt finds significant improvements in math achievement, her instrumental

\footnotetext{
${ }^{3}$ Students that lose the lottery can attend GT programs in their local school, other magnet schools (based on other specializations), or charter schools. The GT programs in these other schools are called neighborhood programs, because they are not designed to attract GT students from other attendance zones.
} 
variables methodology suffers from weak instruments, leaving open the potential that her estimates are biased. Our work offers a wider scope of inquiry, and further offers the two distinct identification strategies. Thus, our study will be the first to establish credibly causal estimates of the impacts of GT programs on student achievement.

Our RD analysis shows that students exposed to GT curriculum for the entirety of $6^{\text {th }}$ grade plus half of $7^{\text {th }}$ grade exhibit no significant improvement in achievement. This is despite substantial increases in average peer achievement on the order of one-fourth to one-third of a standard deviation, an increased likelihood of being placed in advanced classes, and the opportunity to attend a GT magnet program. We also find no improvements within student subgroups. While our estimates are local to the RD margin we note that, due to the multiple factors that go into the eligibility index, students near the discontinuity show wide variation in achievement levels, leading to a more generalizable interpretation than most RD designs. For example, students who score precisely at the eligibility threshold range from 45 to 97 national percentile rankings in reading and between 55 and 98 percentiles in math. ${ }^{4}$

The lottery results, comparing students in the two premier GT magnet schools to other GT students, also show little improvement in overall $7^{\text {th }}$ grade achievement with the exception of science scores. This is despite improvements in mean peer achievement on the order of one standard deviation, and higher quality teachers as measured by teacher fixed effects. We also note that, although the lottery analysis answers a different question than the RD, it has the advantage of evaluating the impact of receiving a more intense treatment for students who would

\footnotetext{
${ }^{4}$ The inter-quartile ranges are 78 to 92 for reading and 83 to 94 for math.
} 
be infra-marginal in the RD framework, as lottery participants tend to be from the upper part of the GT distribution. ${ }^{5}$

There are several pathways through which exposure to GT programs might increase student achievement. We demonstrate below that teachers in the premier schools with lotteries have larger fixed effects on achievement than teachers who instruct lottery losers, and that marginal students in the GT program take more advanced courses than marginal students not in a GT program. ${ }^{6}$ Additionally, while we cannot directly assess these mechanisms, GT may induce parents to become more involved in their children's schooling or the additional schooling options available to GT students may generate a better match between students and their schools.

Nonetheless, we find that peer effects amongst GT students are especially interesting in this context given the large improvements in peer quality from enrolling in GT. If peer effects follow a monotonic model whereby being surrounded by higher achieving students improves one’s own achievement, as found in Imberman, Kugler and Sacerdote (2009), better peers should be helpful. For a marginal GT student, however, the peer effect may not necessarily be positive. That is, a marginal GT student is likely to go from being near the top of the regular class to being near the bottom of the GT class. Further, even students in the middle of the GT distribution may experience a similar loss of ranking in the magnet GT schools compared to neighborhood schools. In this context it is possible that an invidious comparison (IC) model proposed by Hoxby and Weingarth (2006), whereby students are demoralized by reductions in their relative ranking or teachers provide more resources to students at the top of the classroom distribution,

\footnotetext{
${ }^{5}$ While the average GT student in $7^{\text {th }}$ grade scores 1 standard deviation above the mean $7^{\text {th }}$ grade student, the lottery participants score 1.6 standard deviations above the mean.

${ }^{6}$ Conversations with school district officials suggests that the GT curriculum is more likely to include more detail and go more in-depth into topics, rather than cover the regular curriculum more quickly and add additional topics (increase breadth).
} 
applies. We present suggestive evidence using both course grades and the ranking of students within each class that indicates invidious comparison may be sufficiently important to balance out the other characteristics of GT programs that would be expected to increase achievement.

\section{The Gifted and Talented Program in LUSD}

LUSD is a very large school district in the Southwestern US with over 200,000 students. The district is heavily minority and very low income, although the minority population is more heavily Hispanic rather than African-American. Panel A of Table 1 show that gifted students are less likely to be economically disadvantaged, more likely to be white, less likely to have limited English proficiency, and perform better on both cognitive and non-cognitive measures of output than non-GT. Schools in LUSD also have a monetary incentive for attracting gifted students as LUSD provides a funding boost of $12 \%$ over the average daily allotment for a regular student.

In order to be identified as GT in LUSD, a student must meet the eligibility criteria set forth in the "gifted and talented identification matrix," which we will refer to as "the matrix.” A copy of the matrix for entry into GT in 2008-09 is provided in Figure 1. The matrix converts scores on standardized tests - Stanford Achievement Test for English speaking students and the Aprenda exam for a subset of Spanish speaking students with limited English proficiency scores on the Naglieri Non-verbal Abilities Test (NNAT), average course grades, teacher recommendations, and indicators for socio-economic status into an index score we call "total matrix points." 7

\footnotetext{
${ }^{7}$ For socioeconomic status, students get 5 extra points (out of a maximum of 108) for having limited English proficiency, being classified as special education or being classified as economically disadvantaged. Students who are members of a minority group get a further 3 point bonus.
} 
Students can meet eligibility requirements in one of two ways. The first is having 56 total matrix points, including at least 16 points from the Stanford Achievement Test or Aprenda and 10 points from the NNAT. $^{8}$ Alternatively, students can qualify by having 62 total matrix points regardless of Stanford, Aprenda and NNAT scores. During $5^{\text {th }}$ grade all students are evaluated for GT, including those who participated in the GT program in elementary school. ${ }^{9}$ This selection framework allows us to model qualification across the eligibility boundary by using a fuzzy RD methodology. Specifically, while all students who meet the requirements above qualify, not all end up being classified as GT because parents are allowed to opt-out of the program, or students may enroll and then withdraw. ${ }^{10}$ Further, some who do not initially meet the requirements later become identified as GT. This is mainly because students qualify for entry in $7^{\text {th }}$ grade after not qualifying in $6^{\text {th }}$, parents appeal the recorded matrix scores by submitting an alternative standardized test taken within the prior 12 months, data is corrected or missing data is added later. $^{11}$

\footnotetext{
${ }^{8}$ Students can reach 16 points from the Stanford Achievement Tests through different combinations of scores on four subjects. For example a student who is in the $90^{\text {th }}$ percentile in math and the $80^{\text {th }}$ percentile in reading will qualify regardless of science and social studies scores. Alternatively a student could meet this requirement by scoring in the $80^{\text {th }}$ percentile in all four exams. See Figure 1 for details on the score to points conversions. For the Naglieri test a score of 104 (no percentiles are given) would be equivalent to 10 matrix points.

${ }^{9}$ Elementary students must re-qualify in $5^{\text {th }}$ grade to maintain their classification in middle school. Students who qualify for GT in middle or high school generally keep their status through graduation, although they can be removed from the GT program if they perform poorly. Those who do not qualify in $5^{\text {th }}$ grade have the opportunity to be re-evaluated in later years at their school's discretion. All students are also evaluated for GT services in kindergarten, but unfortunately the matrix data was incomplete prohibiting us from evaluating the GT program in elementary schools.

${ }^{10}$ Another reason a student may not show up in the data as GT is if his or her school does not have enough GT certified teachers to provide the required services. However, this is very rare as only 2 of the 41 traditional middle schools in LUSD had no GT students in $7^{\text {th }}$ grade in 2009-10.

${ }^{11}$ Below we show that the missing data does not appear to substantially influence our results. Additionally, results for $6^{\text {th }}$ grade show a similar sized likelihood of being GT to the left of the boundary, suggesting that qualification in $7^{\text {th }}$ grade rather than $6^{\text {th }}$ is not an important factor.
} 
Table 1 also shows means from the lottery sample in panel B. The students in the lottery are significantly stronger academically than the average GT student in panel A, consistent with our view that the lottery results reflect a LATE for students in the upper portion of the GT distribution while the RD estimates reflect impacts on the "marginal" GT students. For example, in $7^{\text {th }}$ grade the lottery participants score 0.6 standard deviations higher than mean GT student. ${ }^{12}$ Lottery participants are also wealthier and whiter than the average GT student. A key element from the lottery sample is the attrition rate. Of the 542 students that entered the lottery, $18.8 \%$ are not in the school district by $7^{\text {th }}$ grade, and in fact, most of these students leave the sample before $6^{\text {th }}$. There is potential for attrition bias in the lottery sample, however, as lottery losers who leave are likely different from winners who leave as evidenced by the slight differences in achievement of winners and losers in Table 1. We will address potential attrition bias in two ways - by reweighting the sample to look like the pre-lottery sample on observables, and through the use of a new bounding analysis proposed by Engberg, Epple, Imbrogno, Sieg and Zimmer (2010). ${ }^{13}$

\section{Model and Specification}

\section{GT Program Evaluation Using Regression Discontinuity}

The objective of the RD analysis is to estimate a LATE that differentiates students who enroll in GT from students who do not, but who are otherwise equivalent. Figure 2 shows the increase in GT identification two years after evaluation ( $7^{\text {th }}$ grade) as a function of the students' matrix points. The gradual increase up to $28 \%$ at the first cutoff (of students with a matrix score

\footnotetext{
${ }^{12}$ Throughout this paper we standardize scale scores from each exam within grade and year across the district.

${ }^{13}$ We also test for selective attrition in the RD sample but find little evidence to suggest it is a problem there.
} 
of 56) reflects missing data, qualifying in $7^{\text {th }}$ grade and the district's appeals process. Upon reaching the first threshold, GT enrollment jumps to 45 percent. Enrollment increases further at a steep rate between the two cutoffs, hitting $79 \%$ at the second cutoff (62 matrix points). After reaching the second cutoff, GT enrollment slightly increases further to 82 percent.

Given the increase in GT over this range is steep but not discontinuous, we convert the two thresholds into a single cutoff. To do this we map components of the matrix scores into three-dimensional space as shown in Figure 3. Each axis reflects one of the three portions of the matrix score that determines eligibility - NNAT points, Stanford/Aprenda points, and other points, which includes socio-economic status, grades and teacher recommendations. Students who are on or above the surface are eligible for GT while those below or behind are ineligible. We then take the Euclidean distance from each student's total matrix points to the closest integer combination on the surface. ${ }^{14}$ The resulting value, which we call the distance to the qualification threshold, equals zero if the student just barely qualifies for GT. Figure 4 shows GT enrollment as a function of Euclidean distance from the qualification threshold. Students just below the cutoff have a $25 \%$ likelihood of being in GT, however students just above the threshold have a likelihood of approximately 79 percent. ${ }^{15}$

Since qualification for GT via the observed matrix score does not translate perfectly with enrollment in GT due to appeals, substitute exams, opt-outs, and data issues, our estimation strategy uses a "fuzzy RD” model where we conduct a two-stage least squares regression within

\footnotetext{
${ }^{14}$ The Euclidean distance is measured as Distance $_{i}=\sqrt{\left(\text { Stanford }_{i}-\text { Stanford }_{s}\right)^{2}+\left(N N A T_{i}-N N A T_{s}\right)^{2}+\left(\text { Other }_{i}-\text { Other }_{S}\right)^{2}}$ where $i$ refers to the student's own score and $s$ refers to the closest integer combination on the surface. We thank Jake Vigdor for first suggesting this method to us.

${ }^{15}$ Note that by construction the distance measure has an empty mass between 0 and 1 and -1 and 0 since the smallest distance to another integer point is 1 .
} 
a range of values that includes the cutoff (Hahn, Todd and Van der Klaauw, 2001; Lee and Lemieux, 2009). For most of this paper we will use ten distance units below and above the cutoff for our bandwidth since the relationships between distance and the achievement outcomes are close to linear over this range, allowing us to use a linear smoother. We show later that our results are not sensitive to the choice of bandwidth. Hence, we estimate the following two-stage least squares (2SLS) model:

$$
\begin{aligned}
& \text { (1) } G T_{i, t+k}=\delta+\gamma \text { Above }_{i t}+\rho_{1} \text { Distance }_{i t}+\rho_{2} \text { Distance }_{i t} \times \text { Above }_{i t}+\boldsymbol{\Omega} \boldsymbol{X}_{i t}+\mu_{i j t+k} \\
& \text { (2) } Y_{i, t+k}=\alpha+\beta G T_{i, t+k}+\lambda_{1} \text { Distance }_{i t}+\lambda_{2} \text { Distance }_{i t} \times \text { Above }_{i t}+\boldsymbol{\Phi} \boldsymbol{X}_{i t}+\varepsilon_{i j t+k}
\end{aligned}
$$

where $A_{b o v e}$ is an indicator for whether student $i$ in year $t$ has a distance measure above the cutoff, Distance is the Euclidean distance of the student's matrix score to the eligibility cutoff, and $X$ is a set of pre-existing ( $5^{\text {th }}$ grade) observable characteristics which includes the $5^{\text {th }}$ grade dependent variable (e.g. lagged achievement), gender, ethnicity, gifted status, and LEP status. GT is an indicator for whether the student is enrolled in a GT program in year $t+k$ and $Y$ is test scores, attendance, or disciplinary infractions in that year. Since students are tested in January of each year, we focus on scores in the second year after evaluation ( $7^{\text {th }}$ grade) as assessment in the first year will only provide five months of program exposure, although we provide estimates for $6^{\text {th }}$ grade outcomes in the online appendix.

\section{GT Magnet Evaluation Using School Lotteries}

LUSD has two middle schools with GT magnet programs that are over-subscribed, and as a result the district uses lotteries to allocate available spaces. ${ }^{16}$ While the losers of the lottery still

\footnotetext{
${ }^{16}$ There are 8 middle schools with GT magnet programs in total (out of 41 traditional middle schools), but only two are over-subscribed. By seventh grade, of the 109 lottery losers, 21 enroll in one of the lottery magnet schools, while
} 
have the opportunity to receive GT services in their neighborhood school, the two magnet schools are considered to be premium schools because of their large proportions of GT students and focus on advanced curricula. ${ }^{17}$

Our analysis compares the performance of students who win the lottery and attend one of the magnet GT programs to those who lose the lottery and either attend a neighborhood GT program in the district, a magnet school based on a different specialty, or a charter school. Hence in the lottery sample we estimate the following 2SLS model conditional on applying for admission to magnet program with a lottery:

$$
\begin{gathered}
\text { (3) } \text { GTMagnet }_{i j t+k}=\delta+\gamma \text { Admitted }_{i j t}+\boldsymbol{\Omega} \boldsymbol{X}_{i t}+v_{j}+\mu_{i j t} \\
\text { (4) } Y_{i j t+k}=\alpha+\beta G T \text { Magnet } \\
i j t+k
\end{gathered}
$$

where GTMagnet is an indicator for attending any GT magnet program, including those that do not hold a lottery, Admitted is an indicator for being offered a slot at a program with a lottery, $\mathrm{X}$ is a set of student level controls, and $v_{j}$ and $\eta_{j}$ are lottery fixed-effects. ${ }^{18}$

One important caveat to the lottery is that students who have an older sibling in the school are exempted from the lottery and automatically given admission. Unfortunately, LUSD was unable to provide us with data on siblings. Nonetheless it is likely that this would have, at most, a negligible impact on our estimates. First of all, while one might be concerned that students with older siblings differ from others in some unobservable way, the pre-selection

only 5 attend one of the other six GT magnet programs. On the other hand, of the 265 lottery winners, only 3 attend one of the other six GT magnets in $7^{\text {th }}$ grade.

${ }^{17}$ One of the two lottery schools also has an attendance zone. GT students from the attendance zone bypass the lottery, hence we drop from our sample any student zoned to that school.

${ }^{18}$ Since we focus only on one cohort, $5^{\text {th }}$ graders in 2007-08 (who are in $7^{\text {th }}$ grade in 2009-10), there is a single lottery fixed-effect indicator in each regression. Models with $6^{\text {th }}$ grade outcomes, and hence two cohorts of students, have three indicators. Also note that coding GTMagnet for students who attend a non-lottery GT magnet as zero instead of one has no effect on the results. 
process for entry - all students need to qualify for GT based on their matrix points and need to follow the same application process for entry into the magnet - mitigates the scope for this type of selection substantially. Second, if such a selection process was occurring we would expect to see differences in observables between students offered a slot in the magnet and those not offered one. As we will show later our lottery sample is very well balanced between "winners," including those accepted under the sibling rule, and "losers."

An additional concern is whether the presence of an older sibling generates a differential impact on magnet students. For example, this could happen if having an older sibling in the school provides a student with help on homework or assistance dealing with teachers. While we cannot completely rule out such a situation, we note that many lottery losers will have older siblings in the school they ultimately attend as well, particularly if they attend their local schools. Hence, unless older sibling benefits differ by magnet status, this phenomenon should have little impact on the estimates.

\section{Regression Discontinuity Estimates of GT Impacts}

\section{Data}

Our data consists of the administrative records from 2007-08 to 2009-10. While we have data for universal assessments conducted in 2006-07, many schools were given exemptions from the new rules that year in order to allow for an orderly transition to the new system. As such, we start our sample in 2007-08, the second year of the mandatory GT assessment, and examine outcomes through the 2009-10 school year. For outcomes we use scale scores standardized across LUSD within grade and year on the Stanford Achievement Test, as well as attendance rates and counts of disciplinary infractions warranting an in-school suspension or more severe 
punishment. The test results are in standard deviation units for math, reading, language, science and social studies exams. ${ }^{19}$ After restricting the sample to a 20 unit band around the cutoff, we look at achievement of approximately 2,600 students in one $7^{\text {th }}$ grade cohort and 5,500 students in two $6^{\text {th }}$ grade cohorts who were evaluated for GT in $5^{\text {th }}$ grade. ${ }^{20}$

\section{Tests of Validity of RD Design}

A primary concern with any regression-discontinuity analysis is that there is a potential for manipulation of the forcing variable (qualification for GT) that determines treatment. Such manipulation could bias the results if it is correlated with outcomes (Lee and Lemieux, 2009). In Online Appendix Figure 1, we provide density plots around the discontinuity. Differences in density around the discontinuity are similar in size to changes at other parts of the distribution, suggesting that manipulation is unlikely to be occurring. ${ }^{21}$

In Table 2 we provide tests of discontinuities in pre-existing ( $5^{\text {th }}$ grade) student characteristics. $^{22}$ We find no discontinuities in race, gender, LEP status, prior gifted status, special education status, eligibility for free or reduced-price lunch, disciplinary infractions,

\footnotetext{
${ }^{19}$ While some LEP students are evaluated using the Aprenda exam, a Spanish-language alternative to the Stanford Achievement Tests, only $0.5 \%$ of $5^{\text {th }}$ grade students in LUSD take only the Aprenda exam and hence have no Stanford scores. Thus, we drop students who only have Aprenda scores.

${ }^{20}$ Within this bandwidth the total matrix scores have an inter-quartile range of 48 to 65 with a minimum of 39 and a maximum of 79 .

${ }^{21}$ Ideally one would like to conduct McCrary's (2008) test. Since there are no observations between 1 and 0 or -1 and 0 (see note 16) and there is positive mass between integers further out, this could mistakenly generate a positive result. Hence, instead we test for discontinuities at the two cutoffs in the total matrix points to check for manipulation. In both cases the test is statistically insignificant.

${ }^{22}$ A related concern is that laid out by Barreca, Guldi, Lindo and Waddell (2010) that heaping in running variables could lead to biased estimates if the heaps are correlated with unobservables and the bandwidths are small enough so that heaps are concentrated only on one side of the cutoff. We do not find any evidence of heaping in the matrix scores. Nonetheless, by construction some heaping will occur in the transformation from matrix scores to Euclidean distances. This is not a problem in our context, however, as our bandwidths are wide enough to include substantial observations both at heaping and non-heaping points on both sides of the cutoff. We will also show later that our results are quite robust to choice of bandwidth.
} 
attendance rates, and achievement with the exception of math. ${ }^{23}$ Given that math is the only covariate that is significant we believe this to be a spurious result. Nonetheless, since achievement is highly correlated over time we correct for this by providing results both with and without controls that include the lagged ( $5^{\text {th }}$ grade) dependent variable.

In column (15) we test whether there is any difference in whether a component of the matrix is missing and find no supporting evidence. This suggests that the fact that some students are missing data is unlikely to affect our estimates. The next two columns address teacher evaluations. ${ }^{24}$ The concern is that if teachers know that a student is short of the qualification threshold they may provide a large enough score for certain types of students to overcome it. If this were the case we would expect to find a discontinuity in the teacher scores or the points in the matrix the student gets from his or her teacher. We find no statistically significant discontinuity in either measure of teacher recommendation. Nonetheless, concerns may still remain about teacher manipulation. Hence, later we provide an additional specification test to check for bias from teacher manipulation through their recommendations.

Finally, in columns (18) though (20) we test whether there is a discontinuous likelihood of being enrolled two years after evaluation. Given that Davis, et al. (2010) find evidence that high income students are more likely to stay in public schools if identified as GT, we check if such a phenomenon occurs in LUSD. We find no statistically significant change in the likelihood of enrollment at the discontinuity regardless of the student's economic status. Hence, given these

\footnotetext{
${ }^{23}$ Online Appendix Figures $2-4$ provide graphical representations of these results. Tests that do not condition on appearing in the data in $7^{\text {th }}$ grade are similar and are provided in Online Appendix Table 1, along with tests using the $6^{\text {th }}$ grade sample. These are also similar for all measures except for females which shows a small but statistically significant increase. In Online Appendix Table 2 we provide estimates without clustering of standard errors. These show no change in the significance levels of the estimates.

${ }^{24}$ Although teacher recommendations are due before achievement scores are calculated, district officials informed us that many teachers submit their recommendations late.
} 
results and those described above we see little evidence that GT qualifications were manipulated in a way that would violate the assumptions underlying the RD methodology.

\section{Results}

Figure 5 presents the initial reduced-form results for three of the five achievement tests, and Figure 6 for the other two. These achievement test results are from $7^{\text {th }}$ grade, and thus encompass about a year and a half of GT program exposure. Our analysis compares students of up to ten distance units above the GT qualification boundary with students who are no more than ten units below. ${ }^{25}$ The coefficient estimates presented in the first panel of Table 3 as well as the means provided in Figure 5 show that there is no improvement in reading or language Stanford scores after a year and a half of GT participation, and that there is a negative and significant point estimate for math. Figure 6 confirms the findings in columns (4) and (5) of Table 3 of no discernable impacts on achievement in social studies or science.

Panel B of Table 3 provides estimates from our preferred specification of equation (2) that contains student level controls measured during $5^{\text {th }}$ grade including the lagged dependent variable, race, gender, economic disadvantage, LEP status, and gifted status. In this panel, all of 2SLS estimates are close to zero while math, reading and social science are negative and all tstatistics are below one. Drawing 95\% confidence intervals around the estimates, we can rule out modest positive impacts of GT on marginal students of 0.06 standard deviations (sd) in math,

\footnotetext{
${ }^{25}$ Online Appendix Figure 5 shows that our Euclidean distance measure correlates very well with total matrix points in a linear fashion.
} 
$0.09 \mathrm{sd}$ in reading, $0.15 \mathrm{sd}$ in language, $0.13 \mathrm{sd}$ in social studies and $0.23 \mathrm{sd}$ in science. The point estimates themselves, however, clearly suggest a zero effect. ${ }^{26}$

In columns (6) and (7) we examine impacts on non-cognitive outputs, disciplinary infractions and attendance rates. While there is no effect on disciplinary infractions, we do find a marginally significant negative effect on attendance rates. The drop in attendance rates of 1.1 percentage points is equivalent to attending school two fewer days in a 180 day school year. As we will demonstrate below, however, this estimate is sensitive to specification.

Panel C presents results that correct for the possibility of teacher manipulation. Even though our earlier tests did not suggest it to be a substantial problem, we are especially concerned because an administrator acknowledged that time deadlines are lax for recommendations leaving opportunities for teachers to "top up" the scores of marginal GT students to put them over the threshold. We address this possibility by replacing a student's matrix points with a synthetic matrix score if the points from a teacher recommendation are potentially pivotal. That is, for students whose other matrix components place them within 10 points of the cutoff, the teacher recommendation, with a maximum of 10 points, is potentially determinative. ${ }^{27}$ Thus for these students we replace their total matrix score with the predicted value from a regression using the full $5^{\text {th }}$ grade sample of total matrix points on all matrix components excluding teacher points:

\footnotetext{
${ }^{26}$ Online Appendix Table 3 provides results for $6^{\text {th }}$ grade. These are similar to those for $7^{\text {th }}$ grade and are more precise due to the addition of an extra year of data. For social studies we can rule out effects of 0.15 sd while for other tests we can rule out impacts of 0.09 sd and higher. Appendix Table 4 provides results with the lagged dependent variable but without the other covariates. These are similar to the results in Panel B of Table 3. Finally Appendix Table 5 shows the results to be robust to the inclusion of middle school fixed-effects.

${ }^{27}$ While teacher recommendations would not be pivotal for students within 10 points above the cutoff, only adjusting scores on one side of the cutoff could introduce bias, particularly if teachers only have information on some of the components at the time they make their recommendations. Hence, we replace scores within 10 points above the cutoff with the synthetic scores as well.
} 


$$
\begin{gathered}
\text { (5)TotalPoints } \\
\text { TobstaclePoints }_{i}+\eta \text { GradePoint }_{i}+\epsilon_{i} .
\end{gathered}
$$

where TotalPoints is the student's final score on the GT qualification matrix, StanfordPoints are the number of matrix points received from performance on Stanford Achievement Tests, NNATPoints are matrix points from the non-verbal abilities test, ObstaclePoints are matrix points from socioeconomic status, and GradePoints are matrix points from the student's average grades in $5^{\text {th }}$ grade. We then convert these "synthetic matrix points" to Euclidean distances from the eligibility surface. This method purges the teacher component from the matrix scores from any case where the teacher could have influence, freeing the estimates from potential biases from teacher manipulation.

The results using the synthetic scores including all controls used in panel B are provided in panel C. Since we are essentially adding measurement error to the first stage, the cutoff instruments are considerably weaker. Nonetheless they remain highly significant indicating that a discontinuity remains. ${ }^{28}$ The 2SLS results show negative and insignificant effects for math, reading, language and social science while science estimates, although positive, are very close to zero. Discipline results are also similar to those in panel B. On the other hand, attendance impacts turn positive, albeit they are statistically insignificant. Given the potential influence of attendance on teacher recommendations, further $\mathrm{RD}$ analyses of this outcome should be interpreted with caution. Nonetheless, since the results for all other outcomes are consistent with the estimates in panel B, we use the baseline model with controls as our preferred specification.

\footnotetext{
${ }^{28}$ In Online Appendix Figure 6 we provide a graph of the first stage for the synthetic teacher scores. The point estimate for the first stage is 0.23 with a standard error of 0.04 .
} 
To test for heterogeneity in program impacts across student characteristics, Table 4 provides 2SLS estimates for $7^{\text {th }}$ grade for various student populations. In general, we find little evidence of differences by gender, demographics, or economic status. The only distinction is that the attendance estimates are more negative for women and black students, but we are cautious in drawing interpretations from this given the results in panel C of Table 3.

In Table 5 we test the sensitivity to our RD estimates to model specification using our preferred model with controls. We find that our estimates hold regardless of whether we add middle school fixed-effects, limit the data to observations with no missing matrix components, use smaller or wider bandwidths, or conduct local linear regressions with optimal bandwidths determined by leave-one-out cross validation. However, when we use a quadratic smoother as the functional form, the estimates show significant improvements in language and science achievement scores. These results become insignificant using a cubic smoother due to larger standard errors. Further inspection, however, suggests that this estimate is being driven by excessive curvature at the discontinuity. Online Appendix Figures 7 and 8 show that the quadratic estimates are mainly driven by random variation at the discontinuity and hence tend to overestimate what appears to be the true impact. As such, we believe a linear smoother captures the correct estimates.

A further concern is that the lack of positive effects may be due to top-coding of the exams. Since GT students are high-achievers many of them may not be able to exhibit growth on achievement tests as they are very close to answering every question correctly. To address this, in Online Appendix Figures $9-13$ we provide distribution plots of raw scores on each of the $7^{\text {th }}$ grade Stanford Achievement Tests for students with Euclidean distances between -10 and 10. In 
all cases the mass of the distribution is centered far from the maximum score. For example in math the modal score is 62 out of 80 while it is 67 out of 84 for reading leaving substantial room for improvement.

Another potential reason for not finding an effect of GT services on student outcomes is that there may be little treatment on students. In Table 6, however, we illustrate the extent to which entering GT generates a measureable treatment. We estimate the impact of GT on peer achievement, where a student's peers are determined by other students in a grade-teacher-course cell, ${ }^{29}$ enrollment in "Vanguard" classes which are pre-Advanced Placement classes with advanced curricula targeted to gifted students, school choices, and teacher quality.

Teacher quality is measured through the use of teacher fixed-effects. These are estimated using a procedure in the spirit of Kane and Staiger (2008). Specifically, we use teacher-student linked achievement data for LUSD middle school students from 2007-08 to 2009-10 to estimate the following model

$$
\text { (6) } Y_{i j k t}=\alpha+\delta Y_{i j k t-1}+\boldsymbol{\Omega} \boldsymbol{X}_{i j k t}+\boldsymbol{\Phi} \boldsymbol{Z}_{i j k t}+\gamma_{\mathrm{k}}+\delta_{\mathrm{j}}+\epsilon_{\mathrm{ijkt}}
$$

where $Y$ is achievement in a given subject, and $X$ is a set of student level controls for economic status, gender, race/ethnicity, special education status, and LEP status. $\mathrm{Z}$ is a set of controls for mean peer achievement (defined at the grade-course-teacher level) in each Stanford Achievement Test. Finally, $\delta_{\mathrm{j}}$ is a set of school fixed effects and $\gamma_{\mathrm{k}}$ is a set of teacher fixed

\footnotetext{
${ }^{29}$ Ideally one would like to use the actual classroom as the peer group. Unfortunately specific course section data are not available. To test the extent to which this is an issue, in Online Appendix Table 6 we sort students in to synthetic classrooms of at most 35 students under the assumption that students are tracked by their $5^{\text {th }}$ grade achievement in the given subject (row (i)) or randomly (row (ii)). With the exception of math in $7^{\text {th }}$ grade the estimated change in peer achievement is similar to those found in Table 6 under both assumptions.
} 
effects. $^{30}$ Kain and Staiger (2008) show that a similar framework closely replicates the results from a randomized allocation of students to teachers. ${ }^{31}$

Table 6 shows in columns (1) to (5) that peer achievement is between 0.24 and 0.35 standard deviations higher for GT students relative to non-GT students. ${ }^{32}$ The table also shows that GT students are more likely to enroll in Vanguard classes and attend a GT magnet program. Interestingly, most of the school switching does not appear to come from students leaving their zoned school for GT magnets. Rather, students appear to move from schools other than their zoned school - mostly non-GT magnets - to the GT magnets. Finally, and perhaps surprisingly, GT students do not appear to get assigned better teachers as measured by teacher fixed effects. This may be due to the fact that in many schools both GT and non-GT students can access advanced classes taught by the same teacher. Nonetheless, the change in peers and the increase in enrollment in advanced classes suggest that the lack of achievement improvements arises in spite of what is generally viewed to be positive treatments. We also note that results for $6^{\text {th }}$ grade are stronger as they show peer differences of 0.37 to 0.46 standard deviations as well as larger differences in Vanguard class enrollment. These are provided in Online Appendix Table 8.

\footnotetext{
${ }^{30}$ We estimate this model such that each observation is assigned a weight equal to the teacher's share of classes taught to a student in a given subject. For example if a student takes a class in US history and another class in geography, then the student will have two observations in the social studies regression, one for each class, where he would be given a weight of $1 / 2$ for each observation. Additionally, since the Stanford exams are given in January, we assign to each student the teachers they had in the spring of the previous academic year and the fall of the current academic year.

${ }^{31}$ Our model diverges from Kain and Staiger (2008) in two key ways. First, they use a random effects rather than fixed effects framework. We prefer the latter as it allows for weaker identification assumptions. Second, they utilize a Bayesian smoother that adjusts estimates for teachers with few observations towards the mean. While this strategy is important when trying to identify the influence of teachers on students, it is inappropriate in our context where we are trying to see if GT students receive higher quality teachers as teachers with fewer observations will tend to be younger and less experienced and hence pushing their estimates to the mean would give us biased measures of actual teacher quality.

${ }^{32}$ Reduced form and first stage results are provided in Online Appendix Table 7.
} 
Below we investigate potential explanations for these findings, but first we turn to our analysis of GT magnet lotteries.

\section{Estimates of the Impact of Attending a GT Magnet Using Randomized Lotteries}

One reason the RD analysis does not show positive impacts from GT services on student outcomes may be that the qualification boundary is set low enough so that students who marginally qualify for GT services are not be able to take advantage of the purported benefits, and thus show no differences with respect to the marginal students not using GT services. Because the RD analysis is a LATE, it is not possible to examine GT effectiveness on other parts of the student quality distribution. Hence, in this section we present results using lotteries for the two GT magnet middle schools. Because the lottery is random, the comparison is across the entire distribution of those who apply. While these students are higher achieving than marginal GT students on average, they also cover a wide range of achievement. The disadvantage, however, is that the lottery losers have a range of alternative experiences, so the comparison treatment is not as clear as for the RD. Additionally, in this analysis we are asking a different question. While in the RD we examine the impact of being in GT or not, in the lottery analysis we identify the impact of gaining a more intense treatment conditional on being classified as GT and applying for the treatment.

\section{Data}

Our lottery sample is derived from the set of $5^{\text {th }}$ grade students determined to be eligible for GT in 2007-08 who apply for admission to one of the two middle schools with an over- 
subscribed GT magnet program. ${ }^{33}$ We restrict our analysis to students who are observed to be enrolled in LUSD in $5^{\text {th }}$ grade as these are the only students for whom we have pre-lottery characteristics. Also, this restriction reduces the likelihood of endogenous attrition as students who enter the lottery from outside LUSD would be more likely to leave if they lose the lottery, as many have previously attended private or charter schools. In addition, one of the two schools has a regular program for students in the attendance zone. ${ }^{34}$ Since students zoned to the school do not participate in the lottery, we drop them from the sample as well.

While admission for non-zoned students is determined by a lottery, our data does not directly provide the lottery numbers or outcomes. Instead we can identify whether a student is offered admission or put on a wait list. We can further identify whether a student is offered a spot off of the wait list which are allocated based on the student's lottery number. Students with an older sibling in the school are exempt from the lottery, but as discussed above we believe the impact of this on our results is negligible. In total the sample includes 542 students who participate in a lottery. Of these 394 are offered admission and 148 are not. By $7^{\text {th }}$ grade 440 students including 331 winners (84\%) and 109 losers (74\%) remain in LUSD. The treatment received by the lottery losers varies, as they can attend GT classes in their neighborhood school, a charter, or in a non-GT magnet school that is open to all students. Since there is some non-

\footnotetext{
${ }^{33}$ The application process involves a single form where students may apply to up to three of the eight magnet schools. Students also list which is their $1^{\text {st }}, 2^{\text {nd }}$ and $3^{\text {rd }}$ choice schools. Unfortunately our data only informs us of whether a person is offered a spot or wait listed and does not have direct information on applications. Hence if a student is offered a spot at his or her first choice school we do not know if they applied for the other school. Nonetheless, we find no cases where a student is placed on the wait list for one of the lottery schools and offered a spot or waitlisted at the second while there are multiple instances whereby students are waitlisted at a lottery school and offered a slot at a non-lottery magnet. Hence, it appears that applying to both lottery magnets was very rare behavior in our data.

${ }^{34}$ The second school does not have zoned students, although it does include a program for students with severe physical disabilities such as blindness and deafness. Students who are enrolled in this alternative program are not included in our lottery sample.
} 
compliance with the lotteries we employ a 2SLS strategy that instruments GT magnet attendance with lottery outcomes. $^{35}$

\section{Tests of Validity of Lottery Design}

Table 7 presents the balancing tests for the lottery sample. The results strongly suggest that the lotteries for both magnet middle schools are conducted in a random way, as the ex-ante baseline ( $5^{\text {th }}$ grade) sample has no significant coefficient on any of the twenty covariates we test. ${ }^{36}$ When we look at the ex-post estimation ( $7^{\text {th }}$ grade) sample, we again find no significant differences between winners and losers except for math which is significantly higher for winners at the $10 \%$ level. Although having one significant result out of twenty regressions can be spurious, it is nonetheless possible that this is due to differential attrition between lottery winners and losers. Indeed, when we estimate the impact of winning a lottery on attrition by $7^{\text {th }}$ grade we find that lottery winners are 11 percentage points less likely to attrit (standard error of 0.04).

We thus use these results to inform our specification and analysis in three ways. First, as with the RD analysis, we present our results both with and without controls for lagged student scores as well as demographic characteristics. Second, we use a weighting procedure in the regressions that mimics the original lottery sample in order to correct for potential attrition bias. To do this we reweight the sample by the inverse of the predicted probabilities from a probit of attrition on $5^{\text {th }}$ grade student characteristics. ${ }^{37}$ Third, we estimate bounds on the impact of GT

\footnotetext{
${ }^{35} \mathrm{By} 7^{\text {th }}$ grade $67 \%$ of lottery winners attend a magnet with a lottery while $17 \%$ attend another school and $16 \%$ leave the district. For lottery losers, $18 \%$ attend a lottery campus in $7^{\text {th }}$ grade while $56 \%$ attend a different school and $26 \%$ leave the district.

${ }^{36}$ Results for the $6^{\text {th }}$ grade sample are similar as are results where standard errors are not clustered. These are provided in Online Appendix Tables 9 and 10.

${ }^{37}$ Results of the probit regression are provided in Online Appendix Table 11.
} 
using a procedure proposed by Engberg, et. al. (2010). The procedure uses observable characteristics to estimate the proportion of the sample that includes students of various types including those who are at risk of leaving LUSD if they lose the lottery. Then, through a generalized method of moments (GMM) estimator, upper and lower bounds are generated. The upper bound assumes students at risk of leaving due to losing the lottery have achievement equal to the mean of students who stay and comply with the lottery results, while the lower bound assumes these same students score at the $95^{\text {th }}$ percentile of the outcome distribution for all staying participants. ${ }^{38}$

\section{Results for GT Magnet Programs}

Two-stage least squares estimates of the impact on student achievement from attending one of the two magnet GT programs are shown in Table 8. Reduced-form estimates are provided in Online Appendix Table 12. ${ }^{39}$ We provide both unweighted (rows 1 and 2) and inverse probability weighted (rows 3 and 4) estimates where the latter corrects for possible attrition bias. In rows (5) and (6) we provide upper and lower bounds that account for potential attrition bias using the Engberg, et al. (2010) methodology.

The results in Table 8 using our preferred specification of weighting with controls (row 4) suggest that, with the exception of science, which shows a 0.28 sd improvement, there is little impact of attending a GT magnet on achievement or attendance. ${ }^{40}$ Due to the small sample sizes

\footnotetext{
${ }^{38}$ That is, the upper bound assumes students at risk of leaving have only average scores, while the lower bound assumes they are in the upper tail. These assumptions are those suggested by Engberg, et al. (2010).

${ }^{39}$ The first stage is always significant at the $1 \%$ level with point estimates of 0.57 (standard error of 0.06 ) for unweighted and 0.47 (0.11) for weighted regressions. Detailed first-stage results are available upon request.

${ }^{40}$ Note that teacher manipulation is not a concern in this identification strategy, hence we can use the attendance results with confidence. Additionally, we do not provide discipline results as only $4 \%$ of students in the lottery sample have any disciplinary infractions in $7^{\text {th }}$ grade.
} 
the estimates are somewhat imprecise, particularly using the inverse-probability weighted model.

Even so, we note that when one looks at row (4) the point estimates for math, reading and social studies are negative and the estimate for language is effectively zero. ${ }^{41}$ Hence, we believe these estimates provide strong evidence of a lack of positive impact of attending a magnet on achievement other than in science. ${ }^{42}$ The bounding analysis in rows (5) and (6) confirm the results in row (4). ${ }^{43}$ Once again we see little to suggest that there is any substantial positive impact on math, reading, language and social studies. For science, the lower bound does drop to zero which suggests that the positive result there may be due to attrition bias, but it nonetheless confirms that there is at least no negative impact on science scores. ${ }^{44}$

In Table 9 we investigate to what extent there is an observable difference in treatment from attending a GT magnet. In particular, we focus on differences in peer achievement and teacher quality as measured by the teacher-fixed effects methodology described in Section 4.3 which are substantial. ${ }^{45}$ Using the weighted estimates, students who attend magnets gain peers, measured at the grade-course-teacher level, who score on average between 0.7 and 1.2 standard

\footnotetext{
${ }^{41}$ Results for $6^{\text {th }}$ grade, provided in Online Appendix Table 13, show somewhat larger, albeit still insignificant in the preferred model, impacts for math and language and no impact for science. They also show a significant negative impact on attendance of -0.6 percentage points (roughly one fewer day per year).

${ }^{42}$ Top-coding of exams is a potentially even larger concern here than in the RD since the achievement levels of the lottery sample are higher. In Online Appendix Figures $14-18$ we provide distribution plots of raw scores on $7^{\text {th }}$ grade exams by lottery winners and losers. Although the mass of achievement is further to the right than in the RD sample, there nonetheless appears to be substantial room for achievement to improve for most students. Hence we do not believe that top-coding explains our lack of positive effects.

${ }^{43}$ We do not provide bounding analyses for attendance as it performs poorly when the mean outcome is centered near a top-code as it tends to estimate outcomes to be above the top-code, which is the case in this sample since mean $5^{\text {th }}$ grade attendance rates are 98.0 with a maximum of 100 .

${ }^{44}$ Online Appendix Table 14 shows lottery results when we use attending a lottery magnet specifically as treatment (e.g. place non-lottery magnets in same category as neighborhood GT) and when we identify students who are taken off the wait list as losing the lottery. In both cases the results are similar to baseline except that science impacts become statistically insignificant.

${ }^{45}$ Estimates without controls and estimates for $6^{\text {th }}$ grade are provided in Online Appendix Table 16 and are similar to those shown in Table 9.
} 
deviations higher than peers for the lottery losers. ${ }^{46}$ Additionally, teachers are of higher quality. A student who attends a GT magnet gains math teachers who add an average of 0.09 sd to student achievement and English and Social Studies teachers who add 0.03 and 0.04 sd to achievement, respectively. ${ }^{47}$ Finally, in Online Appendix Table 17 we investigate whether there is any variation in the estimates by student types. Due to the small sample we are limited in how finely we can cut the data, but nonetheless we find no discernable patterns across subpopulations. Hence it is clear that GT magnet students gain large improvements in their educational environment yet provide little evidence of improvement in achievement except in science. In the next section we discuss some potential explanations for the lack of positive impacts in both the RD and lottery analyses despite the apparent improvements.

\section{Discussion}

Given that we have established that GT students experience substantial treatments including better peers, more advanced courses (in the RD analysis), and higher quality teachers (in the lottery analysis), it is perplexing that we find little evidence of positive impacts on achievement. One possibility is that our achievement measure is not well suited to discerning improvements in gifted students. This would be particularly worrisome if we were to use a state accountability exam targeted towards low achieving students, but less of an issue with Stanford Achievement Test. Indeed, we have already shown that there is little evidence of bunching near

\footnotetext{
${ }^{46}$ In Online Appendix Table 15 we provide results under assumptions of student sorting into sections by ability or randomly as was done in Appendix Table 6 for the $\mathrm{RD}$ analysis. The results generally show similar levels of peer improvement where the difference does not fall below 0.5 standard deviations in any case.

${ }^{47}$ As in the RD analysis, we also look at differences in course level. While there are no significant differences in $7^{\text {th }}$ grade in the likelihood of enrolling in Vanguard courses, in $6^{\text {th }}$ grade students who attend magnets are approximately 10 percentage points more likely to take vanguard courses in math, English and social studies while they are 9 percentage points more likely to take Vanguard in science.
} 
the maximum score (top-coding) in either the RD or lottery samples. Nonetheless, it is possible that the additional course material taught in GT classes may not be well aligned with topics covered in the achievement test. ${ }^{48}$ While we cannot rule out this possibility, we note that the improvement in peers would be expected to generate higher achievement even if the curriculum is not well targeted to the exam.

Another potential explanation is marginal students may suffer due to difficulty with more advanced material. In this view, the eligibility cut-off may be set at an inappropriate level as it leads the district to classify students who are unable to deal with the advanced GT material. While this explanation could be relevant for the $\mathrm{RD}$ results, we demonstrate that the lottery sample includes higher achieving students for whom the advanced material would be more suitable. We therefore end up with a puzzle whereby we have a lack of impact from a very large change in peer achievement and other inputs that are generally thought to improve achievement.

Given the strength with which peer effects have been found to operate in several different contexts, one would expect that we would find achievement improvements simply from the peer effects alone (Angrist and Lang, 2004; Duflo, Dupas and Kremer, 2010; Hoxby and Weingarth, 2006; Imberman, Kugler and Sacerdote, 2009; Lavy, Paserman and Schlosser, 2008; Lavy and Schlosser, 2007). Nonetheless, one possible reason for finding no impact of the differential GT resources is that the peer effect, in addition to the potential benefits found in the literature cited above, also has a potential cost as entering GT may reduce a student's relative ranking within the class. This could generate negative impacts through an invidious comparison model of peer

\footnotetext{
${ }^{48}$ Ideally, one would like to test some outcomes that might better align with the GT curriculum such as collegegoing, SAT scores, and AP/IB exam scores. Unfortunately, since the matrix and lottery data are only available for the last few years, not enough time has elapsed to investigate these outcomes.
} 
effects where one's own performance falls with a reduction in one's position in the withinclassroom achievement distribution (Hoxby and Weingarth, 2006).

There is substantial evidence from the educational psychology and sociology literature, moreover, that students who are placed in higher achieving ability groups can be psychologically harmed. A measure that is commonly used in this literature is the idea of a student's "self concept," how a student perceives his or her own abilities relative to an objective metric such as achievement. Marsh, Chessor, Craven and Roche (1995) compare GT students to observably similar students in mixed GT and non-GT classes and find that GT students show declines in their math and reading self concept. Additionally, Zeidner and Schleyer (1999) find lower self concept and more test anxiety in gifted students in ability segregated classrooms. Similar results are also found by Preckel, Gotz and Frenzel (2010) and Ireson, Haliam and Plewis (2010).

Since we do not have direct evidence on student confidence, we make use of student course grades to test whether the necessary conditions are met for an invidious comparison model to be valid. It is uncertain to what extent course grades reflect absolute levels of achievement compared to achievement relative to other students. Nonetheless, course grades are used by students to assess their own performance, and thus may provide some information as to how students perceive their own relative rank. Additionally, although it is difficult to establish causality, there is nonetheless a link between grades and students' self-concept (Marsh, Trautweing, Ludtke, Koller and Baumert, 2005), satisfaction (Howard and Maxwell, 1980), and self-worth/self-esteem (Crocker, Karpinski, Quinn and Chase, 2003; Owens, 1994). In Panel I of Table 10 we provide estimates of the impact of GT enrollment on course grades in the RD model and of attending a GT magnet on grades in the lottery analysis. In both cases there are clear 
reductions in grades. For the RD sample grades fall by a statistically significant 4 points out of 100 (3 points changes a grade from a $\mathrm{B}+$ to a $\mathrm{B}$, for example) in math and by 2 to 3 points in other subjects, although these estimates are not statistically significant for $7^{\text {th }}$ grade. ${ }^{49}$ For the lottery analysis the grade reductions are even more dramatic with drops of 7 points in math, 8 in science, and 4 in social studies using the inverse-probability weighted regressions.

In addition to the raw grades it is useful to consider how students' rankings within their peer groups differ by treatment status, as this provides a direct measure of how a student perceives his or her position in the achievement distribution. We assume that students mostly compare themselves to their school-mates who take the same courses. Thus, we rank students within each school-grade-course cell by their final course grades and convert these rankings to percentiles. Figures 7 and 8 demonstrate that the rankings based on $7^{\text {th }}$ grade courses exhibit notable drops when students cross the GT eligibility threshold. In panel II.A of Table 10, we provide regression results while adding controls for race, gender, economic disadvantage, LEP, and prior gifted status. The results show that marginal GT students have a relative rank of 13 to 21 percentiles lower than marginal non-GT students in $7^{\text {th }}$ grade. Panel II.B provides the impact of attending a GT magnet on rank and finds that magnet students in $7^{\text {th }}$ grade are nearly 30 percentile rankings lower than the non-magnet students.

To the extent that the negative estimates for grades and rank in the $\mathrm{RD}$ analysis reflects absolute changes in learning, this suggests that the more difficult course work could be ill suited to students at the eligibility margin. However, we would not expect the lottery participants to be ill suited to more difficult coursework given their high positions in the GT achievement

\footnotetext{
${ }^{49}$ In the RD sample we also find a significant drop in reading grades in $6^{\text {th }}$ grade, and among students who take reading in $7^{\text {th }}$ grade of four points. For the lottery sample, however, only a handful of students take reading in $7^{\text {th }}$ grade and hence the estimates are very imprecise.
} 
distribution. Additionally, we find little difference in the likelihood of enrolling in a "Vanguard" class between lottery winners and losers which serves as a proxy for curricular differences. Thus, it seems likely that some portion of the grade effects reflect changes in relative rank. Hence, the necessary conditions are clearly met for invidious comparison to play a role offsetting the expected positive impact of course selection, teacher quality, and peer effects.

\section{Summary and Conclusion}

In this paper, we identify the impact of providing gifted and talented services on student achievement and behavior. We exploit a unique universal evaluation in a large urban school district in the Southwest US where all students are evaluated for GT eligibility in $5^{\text {th }}$ grade regardless of prior GT status. This allows us to specify a regression discontinuity for students on either side of the eligibility cutoff, and examine achievement, attendance and discipline differences by $7^{\text {th }}$ grade. We also exploit a second data set, where two of the middle schools with GT magnet programs in this district are over-subscribed and conduct lotteries to determine admission amongst a pool of eligible GT students. The advantage of the two different identification strategies is that we examine not only the marginal GT students in the RD, but also a much wider portion of the ability distribution in the lottery analysis. The caveat in our strategies, however, is that the alternative to GT treatment varies. Marginal students not admitted to the GT program take "regular" classes, while students that lose the lottery receive GT services but in a less intensive atmosphere than that provided in the magnet schools.

Our analysis shows that both the RD and lottery samples meet the standard validity tests, with the main exception that lottery losers are more likely to leave the district. We correct for attrition in the lottery sample through inverse probability weighting for our estimates and we also 
generate coefficient bounds using a procedure proposed by Engberg, et al. (2010).

The RD results indicate that GT services generate little impact on achievement for students on the margin of qualifying. For the lottery analysis we also find little evidence of improvement in achievement or attendance with the exception of science. These results are surprising given that we find large improvements in peer achievement on the order of 0.3 standard deviations in the RD analysis, and 0.7 to 1.2 standard deviations in the lottery analysis. In addition, we find that students on the margin of GT eligibility enroll in more advanced classes, while students that gain admittance to the premier GT magnet schools gain higher quality teachers. The estimates from these two samples and specifications are reduced forms, in that they do not differentiate among the many mechanisms by which student achievement might be impacted. Nonetheless, we are able to rule out maximum score truncation as a potential explanation. Additionally, while a lack of alignment of the curriculum to the tests could play a role, it does not explain the lack of response to substantial improvement in peers. Further, while difficulty with the advanced material could explain the RD results for marginal students, it does not explain the magnet lottery results.

Finally, we find that raw course grades and students' relative rankings amongst his or her peers as measured by grades fall substantially in both the RD and lottery models. Along with the lack of achievement improvements in spite of large improvements in peer quality, this result is consistent with an invidious comparison model of peer effects, whereby students are demoralized or garner fewer teacher resources by being placed lower in the achievement distribution of their class. The possibility that GT students are subject to invidious comparisons is suggestive of limitations to the benefits of having better peers and more educational inputs. 


\section{References}

Angrist, Joshua and Kevin Lang. "Does Schooling Integration Generate Peer Effects? Evidence from Boston’s Metco Program,” American Economic Review, 94 (2004): 1613-1634.

Argys, Laura, Daniel Rees, and Dominic Brewer. "Detracking America's Schools: Equity at Zero Cost?" Journal of Policy Analysis and Management 15, no. 4 (1996): 623-645.

Barecca, Alan I., Melanie Guldi, Jason M. Lindo, and Greg R. Waddell. "Running and Jumping Variables in Regression Discontinuity Designs.” University of Oregon, mimeo (2010).

Betts, Julian, and Jaimie Shkolnik. "The Effects of Ability Grouping on Student Achievement and Resource Allocation in Secondary Schools." Economics of Education Review 19, no. 1 (2000): 1-15.

Bhatt, Rachana. "The Impacts of Gifted and Talented Education." SSRN Working Paper No. 0911 (2009).

Crocker, Jennifer, Andrew Karpinski, Diane M. Quinn and Sara K. Chase. "When Grades Determine Self-Worth: Consequences of Contingent Self-Worth for Male and Female Engineering and Psychology Majors.” Journal of Personality and Social Psychology 85, no. 3 (2003): $507-516$.

Davis, Billie, John Engberg, Dennis N. Epple, Holger Sieg, and Ron Zimmer, "Evaluating the Gifted Program of an Urban School District using a Modified Regression Discontinuity Design,” NBER Working Paper \#16414, September, 2010.

Duflo, Esther, Pascaline Dupas, and Michael Kremer. "Peer Effects, Teacher Incentivers, and the Impact of Tracking: Evidence from a Randomized Evaluation in Kenya," American Economic Review, forthcoming.

Engberg, John, Dennis Epple, Jason Imbrogno, Holger Sieg and Ron Zimmer. "Evaluating Education Programs That Have Lotteried Admission and Selective Attrition.” University of Pennsylvania, miemo (2010).

Epple, Dennis, Elizabeth Newton, and Richard Romano. "Ability Tracking, School Competition, and the Distribution of Educational Benefits." Journal of Public Economics 83, no. 1 (2002): $1-48$.

Figlio, David, and Marianne Page. "School Choice and the Distributional Effects of Ability Tracking: Does Separation Increase Equality?" Journal of Urban Economics 51, no. 3 (2002): 497-514. 
Hahn, Jinyong, Petra Todd, and Wilbert Van der Klaauw. "Identification and Estimation of Treatment Effects With a Regression-Discontinuity Design." Econometrica 69, no. 1 (2001): 201-209.

Howard, George S. and Scott E. Maxwell. "Correlation Between Student Satisfaction and Grades: A Case of Mistaken Causation?” Journal of Educational Psychology 72, no. 6 (1980): $810-820$.

Hoxby, Caroline and Gretchen Weingarth. "Taking Race Out of the Equation: School Reassignment and the Structure of Peer Effects,” American Economic Association Annual Meetings, http://www.aeaweb.org/annual_mtg_papers/2006/0108_1300_0803.pdf (2006).

Imberman, Scott A., Adriana D. Kugler, and Bruce I. Sacerdote. "Katrina's Children: Evidence on the Structure of Peer Effects from Hurricane Evacuees." University of Houston, mimeo (2009).

Ireson, Judith, Susan Haliam and Ian Plewis. "Ability Grouping in Secondary Schools: Effects on Pupil’s Self-Concepts.” British Journal of Educational Psychology 71, no. 2 (2010): 315 326.

Kane, Thomas J. and Douglas O. Staiger. "Estimating Teacher Impacts on Student Achievement: An Experimental Evaluation.” NBER Working Paper No. 14607 (2008).

Kulik, Chen-lin, and James Kulik. "Ability Grouping." In Handbook of Gifted Education, edited by Nicholas Colangelo and Gary Davis, 230-242. Boston: Allyn and Bacon (1997).

Lavy, Victor, M. Daniele Paserman and Analia Schlosser. "Inside the Black Box of Ability Peer Effects: Evidence from Variation in High and Low Achievers in the Classroom," NBER Working Paper no. 14415 (2008).

Lavy, Victor and Analia Schlosser. "Mechanisms and Impacts of Gender Peer Effects at School," NBER Working Paper no. 13292 (2007).

Lee, David, and Thomas Lemieux. "Regression Discontinuity Designs in Economics." NBER Working Paper No. 14723, 2009.

Marsh, Herbert W., Danuta Chessor, Rhonda Craven and Lawrence Roche. "The Effects of Gifted and Talented Programs on Academic Self-Concept: The Big Fish Strikes Again.” American Educational Research Journal 32, no. 2 (1995): 285-319.

McCrary, Justin. "Manipulation of the Running Variable in the Regression Discontinuity Design: A Density Test.” Journal of Econometrics 142, no. 2 (2008): 698 - 714. 
Neal, Derek, and Diane Whitmore Schanzenbach. "Left Behind by Design: Proficiency Counts and Test-Based Accountability." Review of Economics and Statistics 92, no. 2 (2010): 263 283.

Owens, Timothy J. “Two Diminsions of Self-Esteem: Reciprocal Effects of Positive Self-Worth and Self-Deprecation on Adolescent Problems.” American Sociological Review 59, no. 3 (1994): 391 - 407.

Preckel, Franzis , Thomas Gotz and Anne Frenzel. “Ability Grouping of Gifted Students: Effects on Academic Self-Concept and Boredom.” British Journal of Educational Psychology 80 (2010), no. 3: 451 - 472.

Reback, Randall. "Teaching to the Rating: School Accountability and the Distribution of Student Achievement." Journal of Public Economics 92, no. 5-6 (2008): 1394-1415.

Zeidner, Moshe and Esther Jane Schleyer. "The Big-Fish-Little-Pond Effect for Academic SelfConcept, Test Anxiety and School Grades in Gifted Children.” Contemporary Educational Psychology 24, no. 4 (1999): 305 - 329. 
Figure 1 - Gifted and Talented Matrix for GT Entry in 2008-09

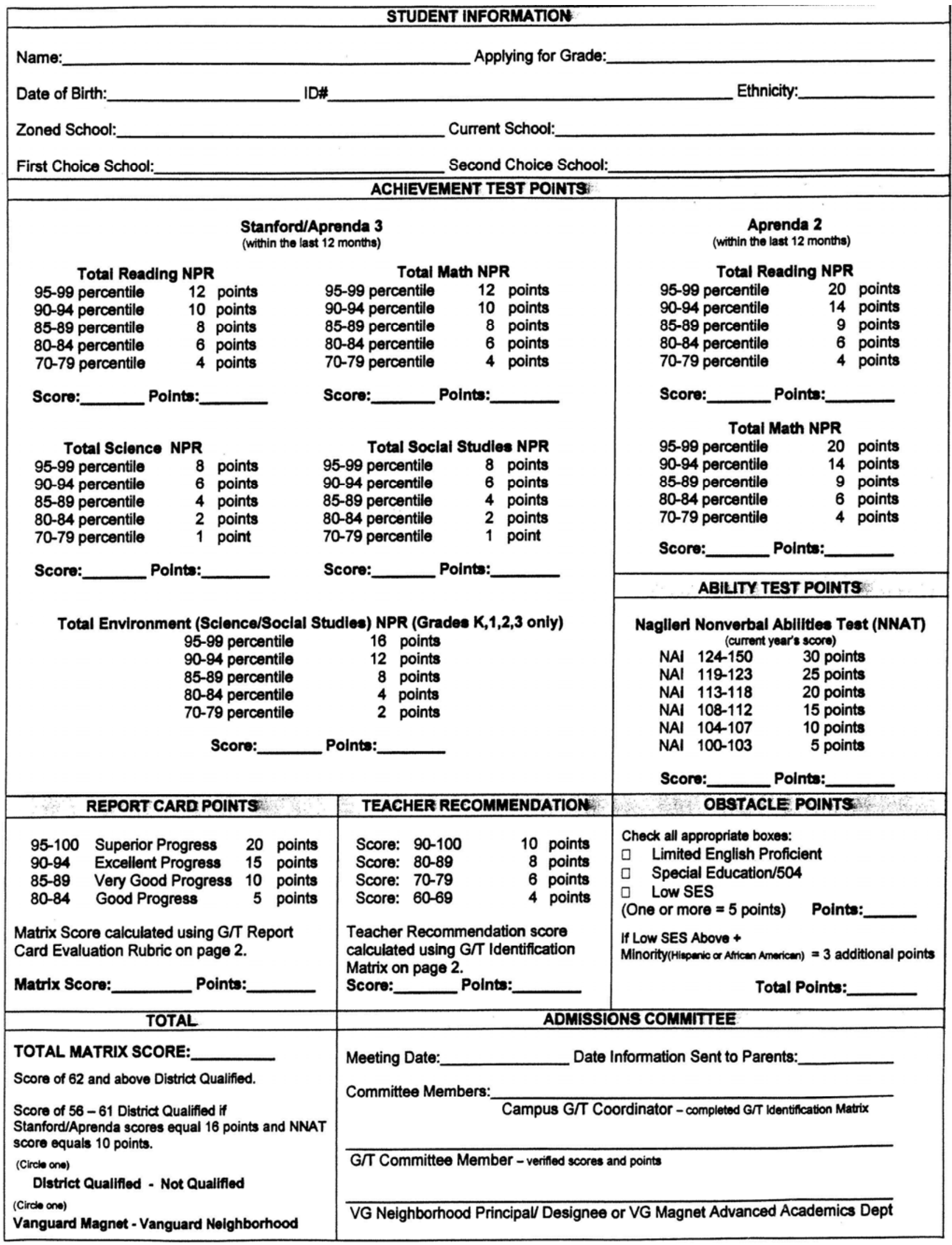




\section{Figure 2: Gifted Status in 7th Grade by 5 th Grade Matrix Score}

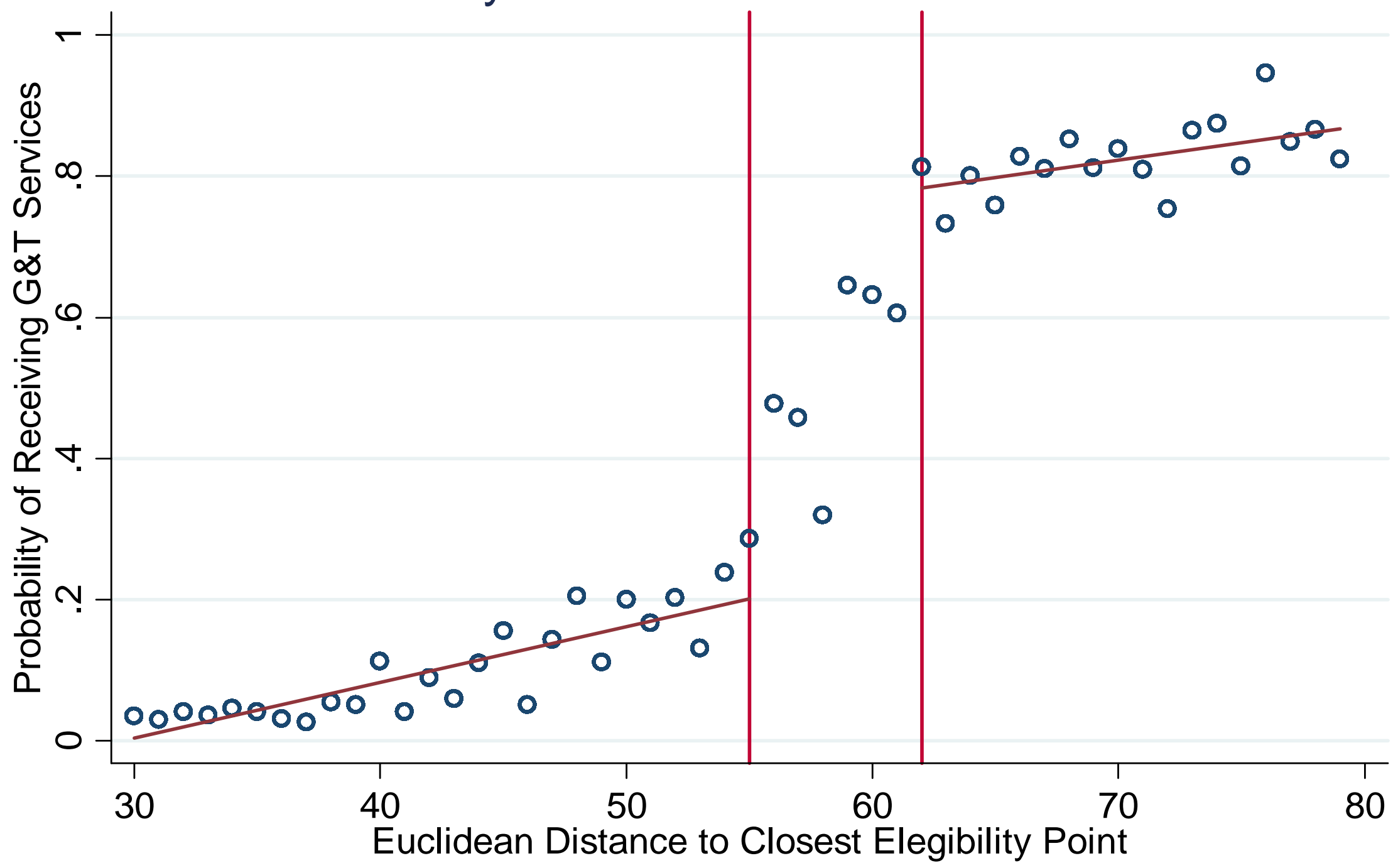


Figure 3: Surface Plot of GT Qualification by Matrix Points

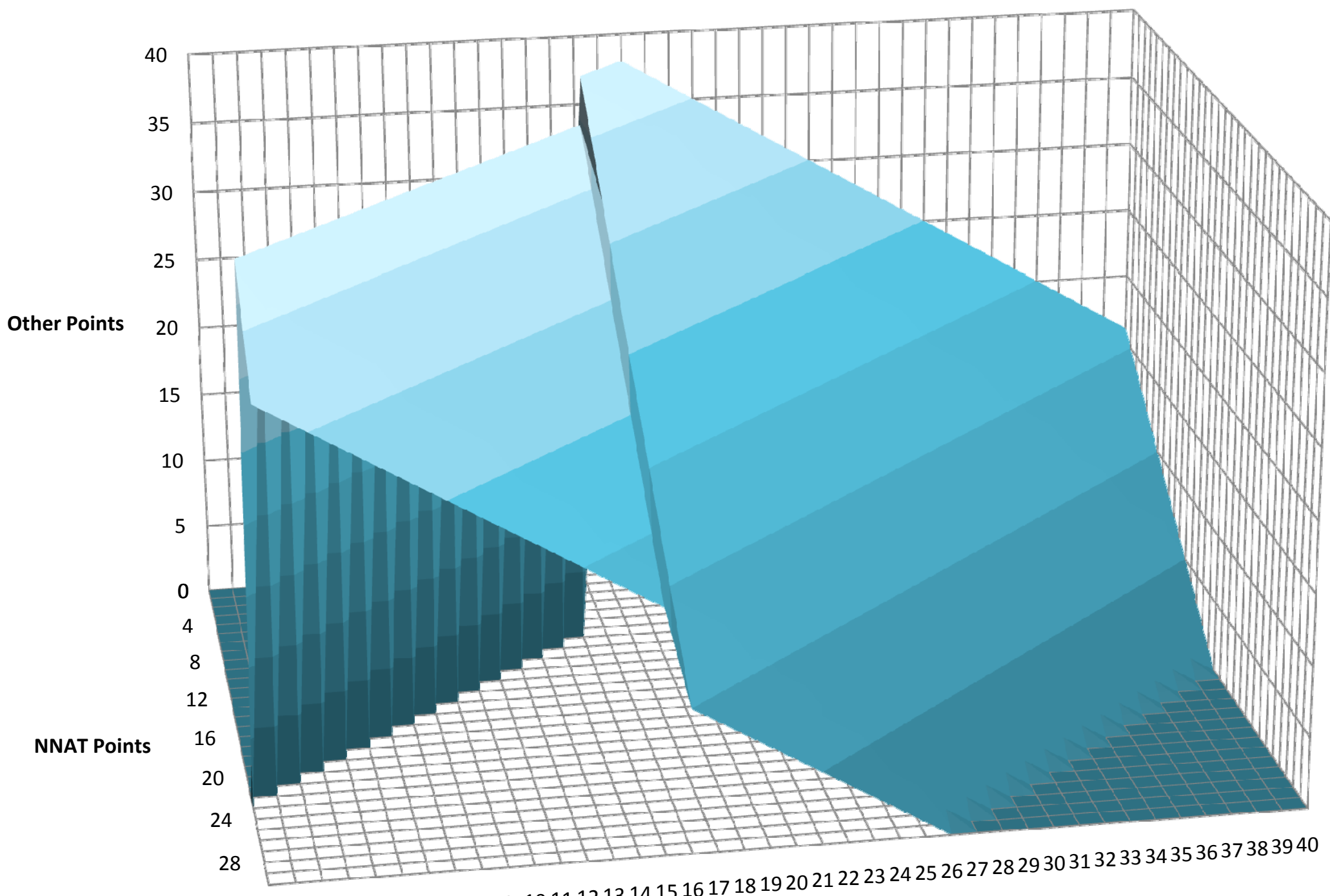

$\begin{array}{rrrrrrrrrrr}0 & 1 & 2 & 3 & 4 & 5 & 6 & 7 & 8 & 9 & 1011 \\ \end{array}$ 
Figure 4: Gifted Status in 7th Grade by Distance to Boundary Based on 5th Grade Matrix Points

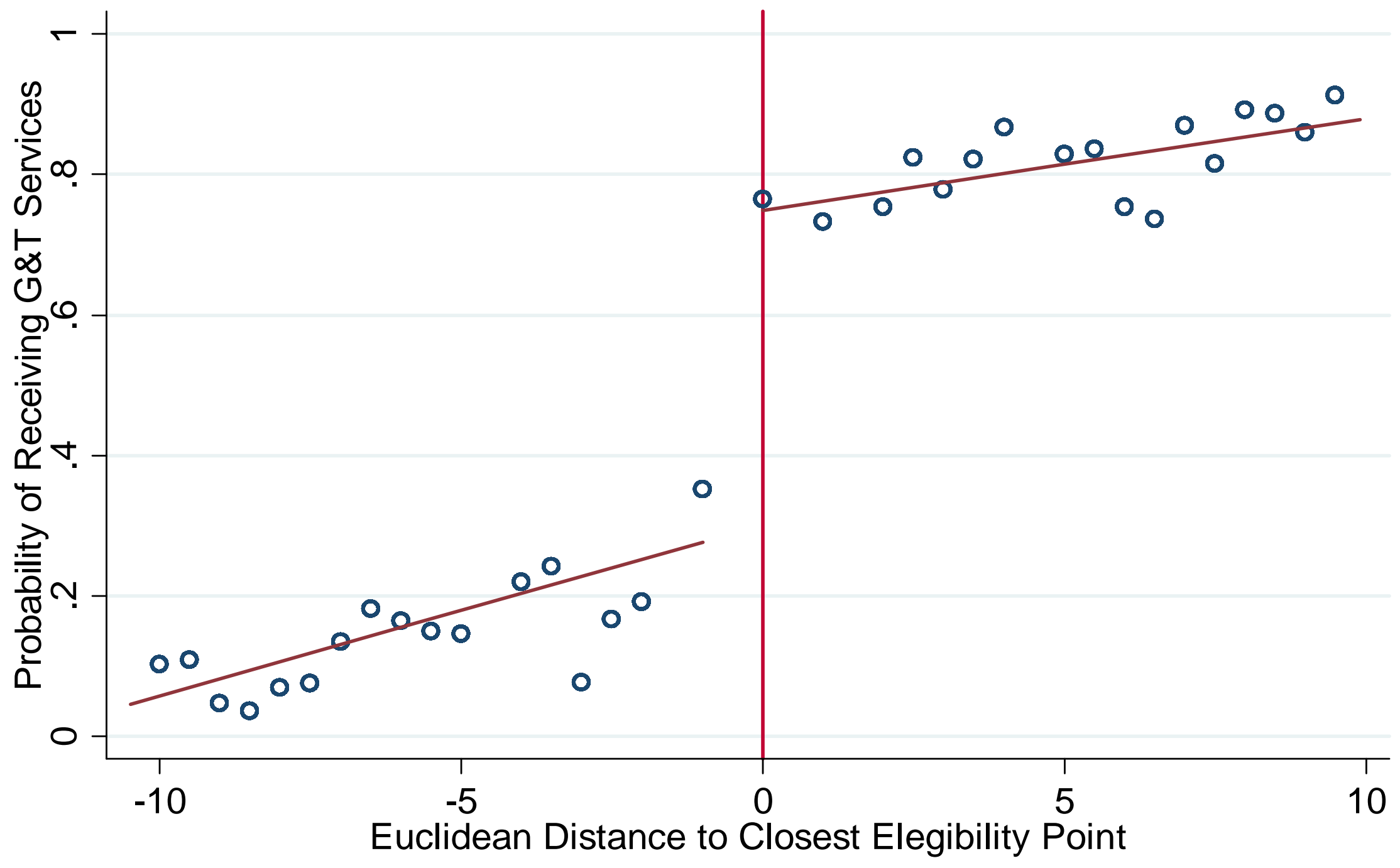




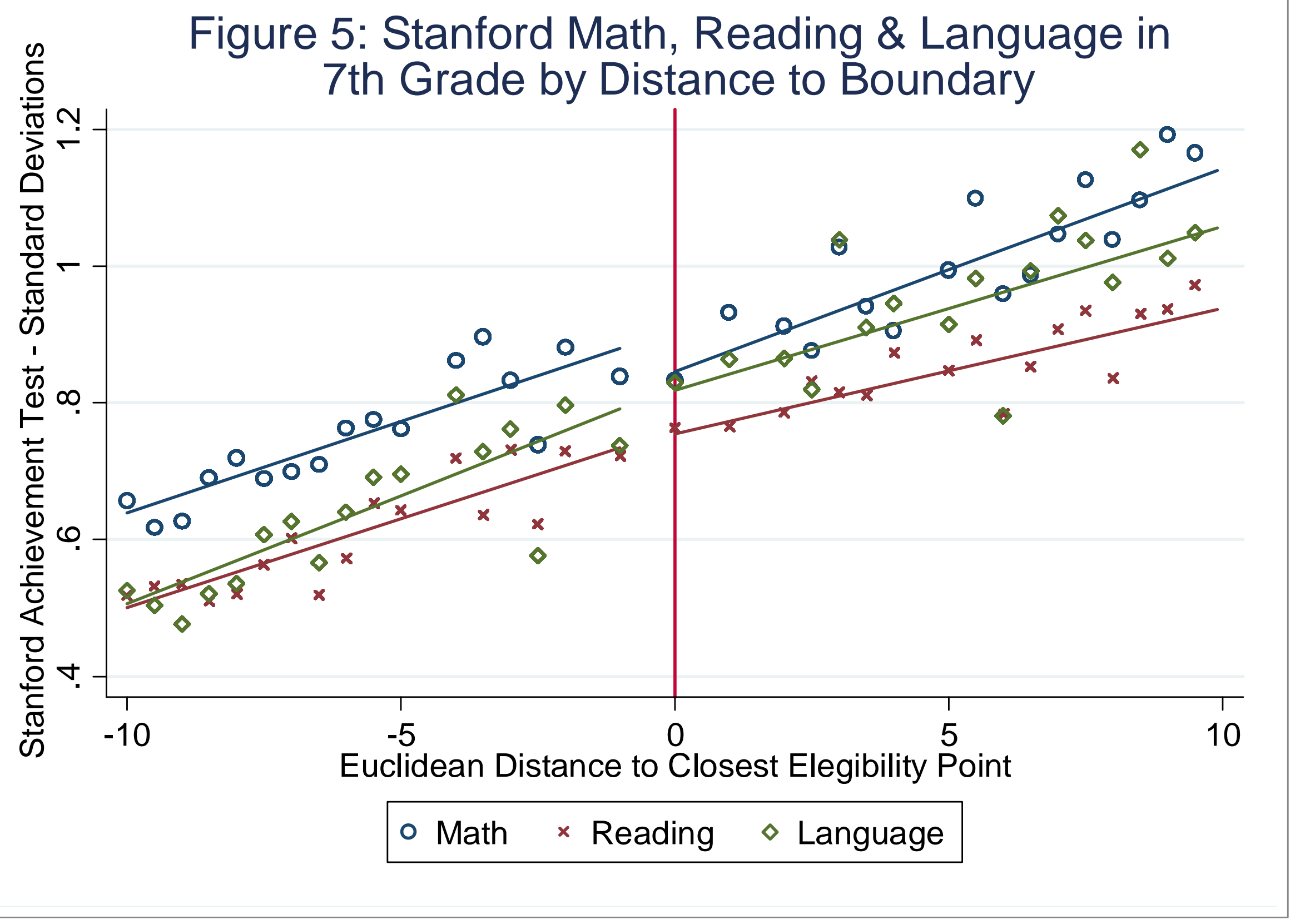




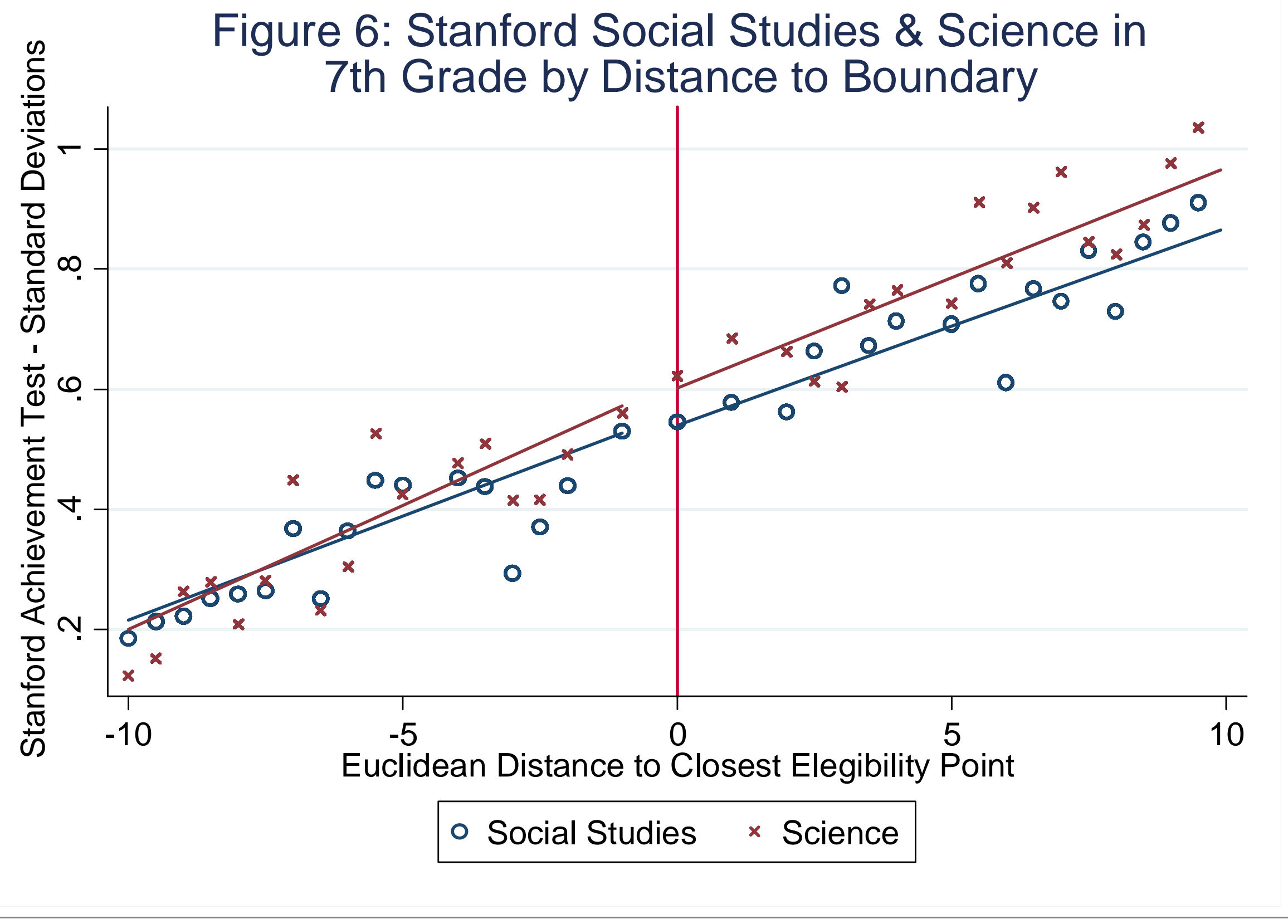




\section{Figure 7: Rank in Course by Final Grade in 7th Grade by Distance to Boundary Math and English}

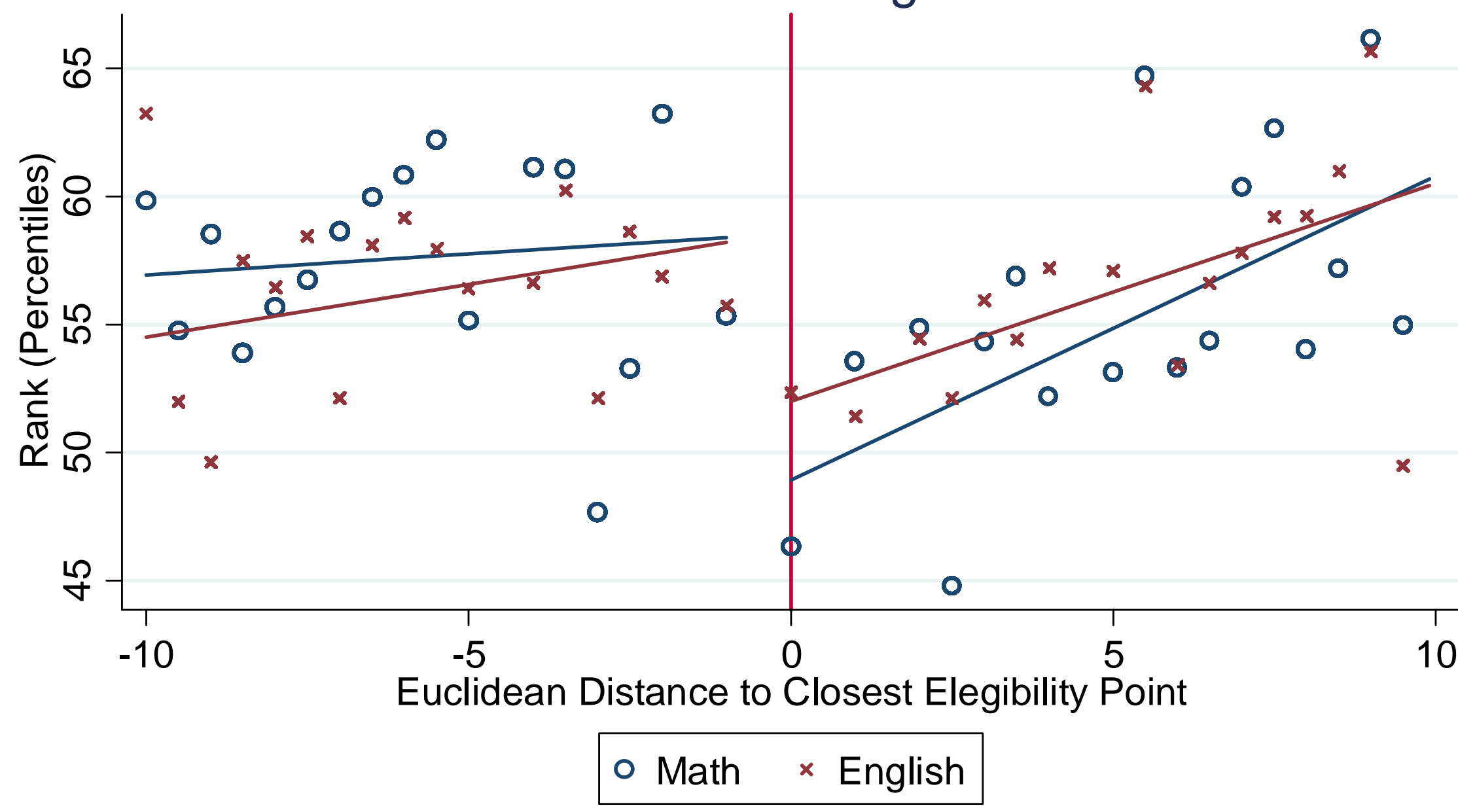

Students with multiple courses in a subject are given the average rank over those courses. 


\section{Figure 8: Rank in Course by Final Grade in 7th Grade by Distance to Boundary Social Studies and Science}

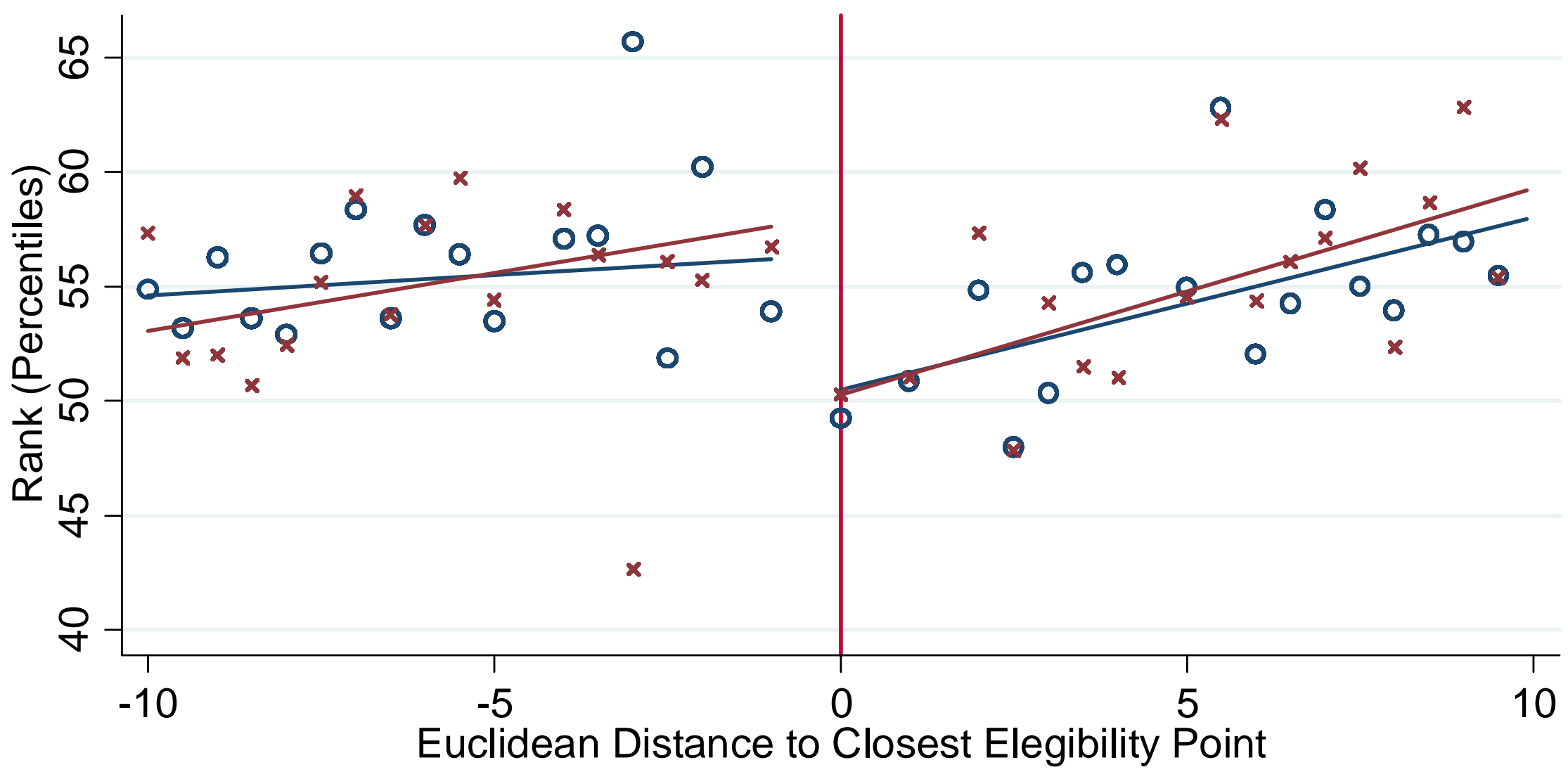

$\circ$ Social Studies $\times$ Science

Students with multiple courses in a subject are given the average rank over those courses. 
Table 1 - Characteristics of Students Evaluated for Middle School GT in 2007-08

\begin{tabular}{|c|c|c|c|c|c|c|}
\hline & \multicolumn{3}{|c|}{ A. All 5th Grade Students } & \multicolumn{3}{|c|}{ B. GT Magnet Lottery Sample } \\
\hline & $\begin{array}{l}\text { Gifted in } \\
\text { 2009-10 (7th } \\
\text { Grade) }\end{array}$ & $\begin{array}{c}\text { Not Gifted in } \\
2009-10\end{array}$ & $\begin{array}{c}\text { Not in Sample in } \\
2009-10\end{array}$ & $\begin{array}{c}\text { In GT Magnet in } \\
2009-10\end{array}$ & $\begin{array}{c}\text { Not in GT Magnet } \\
\text { in } \\
2009-10\end{array}$ & $\begin{array}{c}\text { Not in Sample in } \\
2009-10\end{array}$ \\
\hline \multicolumn{7}{|c|}{ A. 5th Grade Characteristics } \\
\hline Female & $\begin{array}{c}0.54 \\
(0.50)\end{array}$ & $\begin{array}{c}0.48 \\
(0.50)\end{array}$ & $\begin{array}{c}0.50 \\
(0.50)\end{array}$ & $\begin{array}{c}0.51 \\
(0.50)\end{array}$ & $\begin{array}{c}0.54 \\
(0.50)\end{array}$ & $\begin{array}{c}0.57 \\
(0.50)\end{array}$ \\
\hline Economically Disadvantaged & $\begin{array}{c}0.59 \\
(0.49)\end{array}$ & $\begin{array}{c}0.89 \\
(0.31)\end{array}$ & $\begin{array}{c}0.81 \\
(0.39)\end{array}$ & $\begin{array}{c}0.24 \\
(0.43)\end{array}$ & $\begin{array}{c}0.41 \\
(0.49)\end{array}$ & $\begin{array}{c}0.17 \\
(0.37)\end{array}$ \\
\hline LEP & $\begin{array}{c}0.23 \\
(0.42)\end{array}$ & $\begin{array}{c}0.37 \\
(0.48)\end{array}$ & $\begin{array}{c}0.28 \\
(0.45)\end{array}$ & $\begin{array}{c}0.02 \\
(0.15)\end{array}$ & $\begin{array}{c}0.06 \\
(0.24)\end{array}$ & $\begin{array}{c}0.04 \\
(0.20)\end{array}$ \\
\hline Asian & $\begin{array}{c}0.11 \\
(0.31)\end{array}$ & $\begin{array}{c}0.02 \\
(0.13)\end{array}$ & $\begin{array}{c}0.03 \\
(0.18)\end{array}$ & $\begin{array}{c}0.28 \\
(0.45)\end{array}$ & $\begin{array}{c}0.16 \\
(0.37)\end{array}$ & $\begin{array}{c}0.19 \\
(0.39)\end{array}$ \\
\hline Black & $\begin{array}{c}0.13 \\
(0.34)\end{array}$ & $\begin{array}{c}0.28 \\
(0.45)\end{array}$ & $\begin{array}{c}0.33 \\
(0.47)\end{array}$ & $\begin{array}{c}0.12 \\
(0.32)\end{array}$ & $\begin{array}{c}0.21 \\
(0.41)\end{array}$ & $\begin{array}{c}0.18 \\
(0.38)\end{array}$ \\
\hline Hispanic & $\begin{array}{c}0.52 \\
(0.50)\end{array}$ & $\begin{array}{c}0.66 \\
(0.47)\end{array}$ & $\begin{array}{c}0.56 \\
(0.50)\end{array}$ & $\begin{array}{c}0.22 \\
(0.41)\end{array}$ & $\begin{array}{c}0.23 \\
(0.42)\end{array}$ & $\begin{array}{c}0.14 \\
(0.35)\end{array}$ \\
\hline White & $\begin{array}{c}0.24 \\
(0.43)\end{array}$ & $\begin{array}{c}0.04 \\
(0.19)\end{array}$ & $\begin{array}{c}0.09 \\
(0.28)\end{array}$ & $\begin{array}{c}0.38 \\
(0.49)\end{array}$ & $\begin{array}{c}0.40 \\
(0.49)\end{array}$ & $\begin{array}{c}0.50 \\
(0.50)\end{array}$ \\
\hline Gifted & $\begin{array}{c}0.68 \\
(0.47)\end{array}$ & $\begin{array}{c}0.06 \\
(0.25)\end{array}$ & $\begin{array}{c}0.15 \\
(0.36)\end{array}$ & $\begin{array}{c}0.85 \\
(0.36)\end{array}$ & $\begin{array}{c}0.85 \\
(0.36)\end{array}$ & $\begin{array}{c}0.83 \\
(0.37)\end{array}$ \\
\hline Stanford Math & $\begin{array}{c}0.74 \\
(0.59)\end{array}$ & $\begin{array}{c}0.06 \\
(0.39)\end{array}$ & $\begin{array}{c}0.18 \\
(0.47)\end{array}$ & $\begin{array}{c}1.61 \\
(0.79)\end{array}$ & $\begin{array}{c}1.39 \\
(0.71)\end{array}$ & $\begin{array}{c}1.72 \\
(1.03)\end{array}$ \\
\hline Stanford Reading & $\begin{array}{c}0.64 \\
(0.41)\end{array}$ & $\begin{array}{l}-0.02 \\
(0.39)\end{array}$ & $\begin{array}{c}0.11 \\
(0.47)\end{array}$ & $\begin{array}{c}1.72 \\
(0.78)\end{array}$ & $\begin{array}{l}1.60 \\
(0.77)\end{array}$ & $\begin{array}{c}1.83 \\
(0.87)\end{array}$ \\
\hline Stanford Language & $\begin{array}{c}0.74 \\
(0.59)\end{array}$ & $\begin{array}{l}-0.16 \\
(0.57)\end{array}$ & $\begin{array}{c}0.01 \\
(0.67)\end{array}$ & $\begin{array}{c}1.61 \\
(0.84)\end{array}$ & $\begin{array}{c}1.48 \\
(0.76)\end{array}$ & $\begin{array}{c}1.83 \\
(0.94)\end{array}$ \\
\hline Stanford Social Science & $\begin{array}{c}0.43 \\
(0.68)\end{array}$ & $\begin{array}{l}-0.61 \\
(0.68)\end{array}$ & $\begin{array}{c}-0.42 \\
(0.80)\end{array}$ & $\begin{array}{c}1.52 \\
(0.86)\end{array}$ & $\begin{array}{l}1.48 \\
(0.84)\end{array}$ & $\begin{array}{c}1.75 \\
(0.91)\end{array}$ \\
\hline Stanford Science & $\begin{array}{c}0.50 \\
(0.66)\end{array}$ & $\begin{array}{l}-0.50 \\
(0.65)\end{array}$ & $\begin{array}{l}-0.30 \\
(0.76)\end{array}$ & $\begin{array}{c}1.47 \\
(0.89)\end{array}$ & $\begin{array}{c}1.36 \\
(0.79)\end{array}$ & $\begin{array}{c}1.61 \\
(0.95)\end{array}$ \\
\hline Disciplinary Infractions & $\begin{array}{l}0.04 \\
(0.26)\end{array}$ & $\begin{array}{l}0.21 \\
(0.73)\end{array}$ & $\begin{array}{c}0.25 \\
(0.87)\end{array}$ & $\begin{array}{l}0.02 \\
(0.15)\end{array}$ & $\begin{array}{l}0.05 \\
(0.24)\end{array}$ & $\begin{array}{c}0.01 \\
(0.10)\end{array}$ \\
\hline Attendence Rate & $\begin{array}{l}98.26 \\
(2.35)\end{array}$ & $\begin{array}{l}97.25 \\
(4.52)\end{array}$ & $\begin{array}{l}96.58 \\
(4.95)\end{array}$ & $\begin{array}{l}98.35 \\
(2.00)\end{array}$ & $\begin{array}{l}97.98 \\
(2.34)\end{array}$ & $\begin{array}{l}97.00 \\
(3.75)\end{array}$ \\
\hline \multicolumn{7}{|c|}{ B, 7th Grade Outcomes } \\
\hline Stanford Math & $\begin{array}{c}1.11 \\
(0.45)\end{array}$ & $\begin{array}{c}-0.40 \\
(0.41)\end{array}$ & - & $\begin{array}{c}1.70 \\
(0.84)\end{array}$ & $\begin{array}{c}1.53 \\
(0.86)\end{array}$ & - \\
\hline Stanford Reading & $\begin{array}{c}0.95 \\
(0.37)\end{array}$ & $\begin{array}{l}-0.31 \\
(0.38)\end{array}$ & - & $\begin{array}{l}1.66 \\
(0.66)\end{array}$ & $\begin{array}{l}1.58 \\
(0.72)\end{array}$ & - \\
\hline Stanford Language & $\begin{array}{c}1.08 \\
(0.57)\end{array}$ & $\begin{array}{c}0.17 \\
(0.58)\end{array}$ & - & $\begin{array}{c}1.59 \\
(0.80)\end{array}$ & $\begin{array}{c}1.44 \\
(0.72)\end{array}$ & - \\
\hline Stanford Social Science & $\begin{array}{c}0.88 \\
(0.64)\end{array}$ & $\begin{array}{l}-0.09 \\
(0.60)\end{array}$ & - & $\begin{array}{c}1.70 \\
(0.88)\end{array}$ & $\begin{array}{c}1.51 \\
(0.80)\end{array}$ & - \\
\hline Stanford Science & $\begin{array}{c}1.00 \\
(0.79)\end{array}$ & $\begin{array}{c}-0.18 \\
(0.71)\end{array}$ & - & $\begin{array}{c}1.72 \\
(0.94)\end{array}$ & $\begin{array}{c}1.36 \\
(0.77)\end{array}$ & - \\
\hline Disciplinary Infractions & $\begin{array}{c}0.28 \\
(1.11)\end{array}$ & $\begin{array}{c}1.25 \\
(2.61)\end{array}$ & - & $\begin{array}{c}0.05 \\
(0.24)\end{array}$ & $\begin{array}{c}0.13 \\
(0.86)\end{array}$ & - \\
\hline Attendence Rate & $\begin{array}{l}97.37 \\
(3.19)\end{array}$ & $\begin{array}{l}95.02 \\
(6.13)\end{array}$ & - & $\begin{array}{l}97.84 \\
(2.52)\end{array}$ & $\begin{array}{l}97.57 \\
(3.16)\end{array}$ & - \\
\hline Observations & 1,919 & 8,748 & 3,652 & 291 & 149 & 102 \\
\hline
\end{tabular}


Table 2 - Reduced-Form Estimates of Discontinuities in Pre-Existing (5th Grade) Student Characteristics

\begin{tabular}{|c|c|c|c|c|c|c|c|c|c|c|}
\hline & $\begin{array}{c}\text { Black } \\
(1) \\
\end{array}$ & $\begin{array}{l}\text { Hispanic } \\
(2) \\
\end{array}$ & $\begin{array}{c}\text { Female } \\
\text { (3) }\end{array}$ & $\begin{array}{l}\text { LEP } \\
(4) \\
\end{array}$ & $\begin{array}{c}\text { Gifted in 5th } \\
\text { Grade } \\
(5) \\
\end{array}$ & $\begin{array}{c}\text { Special } \\
\text { Education } \\
(6) \\
\end{array}$ & $\begin{array}{c}\text { Free / } \\
\text { Reduced-Price } \\
\text { Lunch } \\
(7) \\
\end{array}$ & $\begin{array}{c}\text { Stanford - } \\
\text { Math } \\
(8) \\
\end{array}$ & $\begin{array}{c}\text { Stanford - } \\
\text { Reading } \\
(9) \\
\end{array}$ & $\begin{array}{c}\text { Stanford - } \\
\text { Language } \\
(10) \\
\end{array}$ \\
\hline Above GT Cutoff & $\begin{array}{c}-0.000 \\
(0.029)\end{array}$ & $\begin{array}{c}0.014 \\
(0.038)\end{array}$ & $\begin{array}{c}0.024 \\
(0.042)\end{array}$ & $\begin{array}{c}0.039 \\
(0.040)\end{array}$ & $\begin{array}{l}-0.050 \\
(0.047)\end{array}$ & $\begin{array}{c}0.005 \\
(0.011)\end{array}$ & $\begin{array}{c}0.049 \\
(0.037)\end{array}$ & $\begin{array}{c}-0.067^{* * *} \\
(0.026)\end{array}$ & $\begin{array}{c}0.006 \\
(0.026)\end{array}$ & $\begin{array}{c}0.006 \\
(0.041)\end{array}$ \\
\hline \multirow[t]{2}{*}{ Observations } & 2,650 & 2,650 & 2,650 & 2,650 & 2,650 & 2,650 & 2,650 & 2,637 & 2,638 & 2,636 \\
\hline & $\begin{array}{c}\text { Stanford - } \\
\text { Social Studies } \\
(11) \\
\end{array}$ & $\begin{array}{c}\text { Stanford - } \\
\text { Science } \\
(12) \\
\end{array}$ & $\begin{array}{c}\text { \# of } \\
\text { Disciplinary } \\
\text { Infractions } \\
(13) \\
\end{array}$ & $\begin{array}{c}\text { Attendance } \\
\text { Rate (\%) } \\
(14) \\
\end{array}$ & $\begin{array}{c}\text { Any Missing } \\
\text { Matrix Data } \\
(15) \\
\end{array}$ & $\begin{array}{c}\text { Teacher Score } \\
(16) \\
\end{array}$ & $\begin{array}{c}\text { Teacher } \\
\text { Points } \\
(17) \\
\end{array}$ & $\begin{array}{c}\text { Enrolled } \\
(18) \\
\end{array}$ & $\begin{array}{c}\text { Enrolled (Free/ } \\
\text { Reduced-Price } \\
\text { Lunch) } \\
(19) \\
\end{array}$ & $\begin{array}{c}\text { Enrolled (Non- } \\
\text { Free/ Reduced- } \\
\text { Price Lunch) } \\
\quad(20)\end{array}$ \\
\hline Above GT Cutoff & $\begin{array}{c}0.040 \\
(0.049)\end{array}$ & $\begin{array}{c}0.004 \\
(0.042)\end{array}$ & $\begin{array}{l}-0.001 \\
(0.028)\end{array}$ & $\begin{array}{c}-0.269 \\
(0.190)\end{array}$ & $\begin{array}{c}0.000 \\
(0.008)\end{array}$ & $\begin{array}{c}2.965 \\
(2.715)\end{array}$ & $\begin{array}{c}0.497 \\
(0.321)\end{array}$ & $\begin{array}{c}0.049 \\
(0.030)\end{array}$ & $\begin{array}{c}0.054 \\
(0.037)\end{array}$ & $\begin{array}{c}0.039 \\
(0.053)\end{array}$ \\
\hline Observations & 2,636 & 2,637 & 2,650 & 2,650 & 2,650 & 2,648 & 2,648 & 3,438 & 2,177 & 1,261 \\
\hline
\end{tabular}

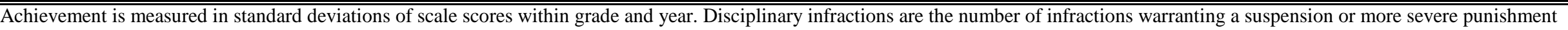

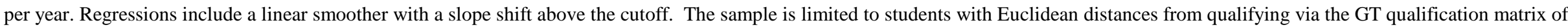

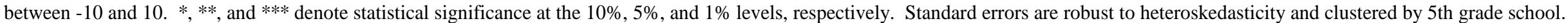

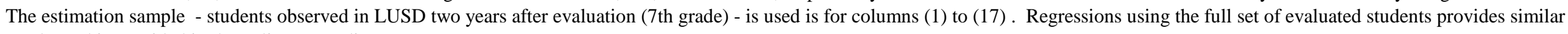
results and is provided in the online appendix. 
Table 3 - Regression Discontinuity Estimates of Impact of Receiving G\&T Services

\begin{tabular}{|c|c|c|c|c|c|c|c|c|}
\hline \multirow[b]{2}{*}{ Model } & \multirow[b]{2}{*}{$\begin{array}{c}\text { Dependent } \\
\text { Variable }\end{array}$} & \multicolumn{5}{|c|}{ Stanford Achievement Test } & \multirow[b]{2}{*}{$\begin{array}{c}\text { Disciplinary } \\
\text { Infractions } \\
(6) \\
\end{array}$} & \multirow[b]{2}{*}{$\begin{array}{c}\text { Attendance } \\
\text { Rate (\%) } \\
(7) \\
\end{array}$} \\
\hline & & $\begin{array}{l}\text { Math } \\
\text { (1) } \\
\end{array}$ & $\begin{array}{l}\text { Reading } \\
(2) \\
\end{array}$ & $\begin{array}{c}\text { Language } \\
\text { (3) } \\
\end{array}$ & $\begin{array}{c}\text { Social } \\
\text { Studies } \\
(4)\end{array}$ & $\begin{array}{c}\text { Science } \\
\text { (5) }\end{array}$ & & \\
\hline \multicolumn{9}{|c|}{ A. Baseline } \\
\hline Reduced Form & Above GT Cutoff & $\begin{array}{c}-0.061 * * \\
(0.030)\end{array}$ & $\begin{array}{l}-0.005 \\
(0.029)\end{array}$ & $\begin{array}{l}-0.004 \\
(0.044)\end{array}$ & $\begin{array}{l}-0.020 \\
(0.038)\end{array}$ & $\begin{array}{l}-0.011 \\
(0.060)\end{array}$ & $\begin{array}{l}-0.006 \\
(0.120)\end{array}$ & $\begin{array}{c}-0.691 * * \\
(0.311)\end{array}$ \\
\hline 2SLS - 1st Stage & Above GT Cutoff & $\begin{array}{c}0.440 * * * \\
(0.057)\end{array}$ & $\begin{array}{c}0.443^{* * *} \\
(0.057)\end{array}$ & $\begin{array}{c}0.442^{* * * *} \\
(0.058)\end{array}$ & $\begin{array}{c}0.440 * * * \\
(0.058)\end{array}$ & $\begin{array}{c}0.440 * * * \\
(0.057)\end{array}$ & $\begin{array}{c}0.436 * * * \\
(0.058)\end{array}$ & $\begin{array}{c}0.438 * * * \\
(0.058)\end{array}$ \\
\hline 2SLS - 2nd Stage & Enrolled in GT & $\begin{array}{c}-0.138 * * \\
(0.068)\end{array}$ & $\begin{array}{c}-0.011 \\
(0.065)\end{array}$ & $\begin{array}{c}-0.008 \\
(0.100)\end{array}$ & $\begin{array}{c}-0.045 \\
(0.085)\end{array}$ & $\begin{array}{l}-0.025 \\
(0.135)\end{array}$ & $\begin{array}{c}-0.014 \\
(0.276)\end{array}$ & $\begin{array}{c}-1.578 * \\
(0.802)\end{array}$ \\
\hline \multirow{2}{*}{\multicolumn{2}{|c|}{ Observations }} & 2,612 & 2,614 & 2,612 & 2,610 & 2,612 & 2,653 & 2,652 \\
\hline & & \multicolumn{7}{|c|}{ B. With Individual Controls } \\
\hline Reduced Form & Above GT Cutoff & $\begin{array}{l}-0.016 \\
(0.022)\end{array}$ & $\begin{array}{l}-0.001 \\
(0.020)\end{array}$ & $\begin{array}{c}0.005 \\
(0.031)\end{array}$ & $\begin{array}{l}-0.007 \\
(0.031)\end{array}$ & $\begin{array}{c}0.008 \\
(0.048)\end{array}$ & $\begin{array}{c}0.003 \\
(0.112)\end{array}$ & $\begin{array}{l}-0.502 * \\
(0.268)\end{array}$ \\
\hline 2SLS - 1st Stage & Above GT Cutoff & $\begin{array}{c}0.465^{* * *} \\
(0.060)\end{array}$ & $\begin{array}{c}0.457 * * * \\
(0.061)\end{array}$ & $\begin{array}{c}0.457 * * * \\
(0.061)\end{array}$ & $\begin{array}{c}0.454 * * * \\
(0.061)\end{array}$ & $\begin{array}{c}0.456 * * * \\
(0.061)\end{array}$ & $\begin{array}{c}0.451^{* * *} \\
(0.060)\end{array}$ & $\begin{array}{c}0.456 * * * \\
(0.060)\end{array}$ \\
\hline 2SLS - 2nd Stage & Enrolled in GT & $\begin{array}{c}-0.035 \\
(0.047)\end{array}$ & $\begin{array}{c}-0.002 \\
(0.044)\end{array}$ & $\begin{array}{c}0.010 \\
(0.068)\end{array}$ & $\begin{array}{c}-0.016 \\
(0.068)\end{array}$ & $\begin{array}{c}0.017 \\
(0.106)\end{array}$ & $\begin{array}{c}0.007 \\
(0.248)\end{array}$ & $\begin{array}{c}-1.101 * \\
(0.653)\end{array}$ \\
\hline \multicolumn{2}{|c|}{ Observations } & 2,597 & 2,600 & 2,596 & 2,594 & 2,597 & 2,650 & 2,649 \\
\hline \multicolumn{9}{|c|}{ C. Using Synthetic Matrix Scores } \\
\hline Reduced Form & Above GT Cutoff & $\begin{array}{l}-0.024 \\
(0.028)\end{array}$ & $\begin{array}{l}-0.028 \\
(0.020)\end{array}$ & $\begin{array}{l}-0.028 \\
(0.039)\end{array}$ & $\begin{array}{l}-0.054 \\
(0.041)\end{array}$ & $\begin{array}{c}0.002 \\
(0.059)\end{array}$ & $\begin{array}{c}0.088 \\
(0.130)\end{array}$ & $\begin{array}{c}0.346 \\
(0.309)\end{array}$ \\
\hline 2SLS - 1st Stage & Above GT Cutoff & $\begin{array}{c}0.229 * * * \\
(0.038)\end{array}$ & $\begin{array}{c}0.232 * * * \\
(0.038)\end{array}$ & $\begin{array}{c}0.230 * * * \\
(0.039)\end{array}$ & $\begin{array}{c}0.228 * * * \\
(0.039)\end{array}$ & $\begin{array}{c}0.229 * * * \\
(0.038)\end{array}$ & $\begin{array}{c}0.230 * * * \\
(0.038)\end{array}$ & $\begin{array}{c}0.229 * * * \\
(0.038)\end{array}$ \\
\hline 2SLS - 2nd Stage & Enrolled in GT & $\begin{array}{c}-0.106 \\
(0.122)\end{array}$ & $\begin{array}{c}-0.121 \\
(0.085)\end{array}$ & $\begin{array}{l}-0.120 \\
(0.170)\end{array}$ & $\begin{array}{c}-0.236 \\
(0.188)\end{array}$ & $\begin{array}{c}0.011 \\
(0.256)\end{array}$ & $\begin{array}{c}0.382 \\
(0.568)\end{array}$ & $\begin{array}{c}1.509 \\
(1.328)\end{array}$ \\
\hline \multicolumn{2}{|c|}{ Observations } & 2,579 & 2,580 & 2,579 & 2,576 & 2,578 & 2,619 & 2,618 \\
\hline
\end{tabular}

Achievement is measured in standard deviations of scale scores within grade and year. Disciplinary infractions are the number of infractions warranting a suspension or more severe punishment per year. Synthetic matrix scores replace matrix scores for students where a teacher recommendation could be pivotal (e.g. total points w/o the recommendation is fewer than 10 away from the relevant cutoff) with the predicted value from a regression of total points on all components excluding the teacher points. See text for details. Controls for race, gender, economic 
Table 4 - 2SLS Estimates of Impact of Receiving G\&T Services Estimates for Sub-Populations

\begin{tabular}{|c|c|c|c|c|c|c|c|c|c|}
\hline & & \multicolumn{6}{|c|}{ Stanford Achievement Test } & \multirow[b]{2}{*}{$\begin{array}{c}\text { Disciplinary } \\
\text { Infractions } \\
(7) \\
\end{array}$} & \multirow[b]{2}{*}{$\begin{array}{c}\text { Attendance } \\
\text { Rate (\%) } \\
(8) \\
\end{array}$} \\
\hline & & $\begin{array}{c}\text { First Stage } \\
(1)\end{array}$ & $\begin{array}{c}\text { Math } \\
(2) \\
\end{array}$ & $\begin{array}{c}\text { Reading } \\
\text { (3) }\end{array}$ & $\begin{array}{c}\text { Language } \\
(4)\end{array}$ & $\begin{array}{c}\text { Social } \\
\text { Science } \\
(5)\end{array}$ & $\begin{array}{c}\text { Science } \\
(6) \\
\end{array}$ & & \\
\hline (1) & Females & $\begin{array}{c}0.531^{* * *} \\
(0.063)\end{array}$ & $\begin{array}{l}-0.023 \\
(0.054)\end{array}$ & $\begin{array}{l}-0.030 \\
(0.049)\end{array}$ & $\begin{array}{l}-0.028 \\
(0.068)\end{array}$ & $\begin{array}{l}-0.041 \\
(0.083)\end{array}$ & $\begin{array}{l}-0.003 \\
(0.114)\end{array}$ & $\begin{array}{c}0.177 \\
(0.230)\end{array}$ & $\begin{array}{c}-1.909 * * \\
(0.726)\end{array}$ \\
\hline & Observations & 1,336 & 1,336 & 1,335 & 1,335 & 1,333 & 1,336 & 1,361 & 1,360 \\
\hline (2) & Males & $\begin{array}{c}0.410^{* * *} \\
(0.076)\end{array}$ & $\begin{array}{l}-0.022 \\
(0.081)\end{array}$ & $\begin{array}{c}0.044 \\
(0.061)\end{array}$ & $\begin{array}{c}0.093 \\
(0.106)\end{array}$ & $\begin{array}{c}0.040 \\
(0.110)\end{array}$ & $\begin{array}{c}0.046 \\
(0.147)\end{array}$ & $\begin{array}{l}-0.205 \\
(0.495)\end{array}$ & $\begin{array}{c}0.029 \\
(1.119)\end{array}$ \\
\hline & Observations & 1,237 & 1,237 & 1,240 & 1,236 & 1,237 & 1,237 & 1,260 & 1,260 \\
\hline (3) & Free/Reduced-Price Lunch & $\begin{array}{c}0.512^{* * *} \\
(0.064)\end{array}$ & $\begin{array}{c}0.009 \\
(0.050)\end{array}$ & $\begin{array}{l}-0.032 \\
(0.047)\end{array}$ & $\begin{array}{c}0.014 \\
(0.079)\end{array}$ & $\begin{array}{l}-0.016 \\
(0.083)\end{array}$ & $\begin{array}{l}-0.031 \\
(0.113)\end{array}$ & $\begin{array}{c}0.160 \\
(0.306)\end{array}$ & $\begin{array}{l}-0.895 \\
(0.671)\end{array}$ \\
\hline & Observations & 1,644 & 1,644 & 1,645 & 1,644 & 1,644 & 1,645 & 1,669 & 1,669 \\
\hline (4) & No Free/Reduced-Price Lunch & $\begin{array}{c}0.366^{* * * *} \\
(0.088)\end{array}$ & $\begin{array}{l}-0.126 \\
(0.097)\end{array}$ & $\begin{array}{c}0.076 \\
(0.076)\end{array}$ & $\begin{array}{c}0.000 \\
(0.130)\end{array}$ & $\begin{array}{l}-0.023 \\
(0.177)\end{array}$ & $\begin{array}{c}0.095 \\
(0.178)\end{array}$ & $\begin{array}{l}-0.613 \\
(0.606)\end{array}$ & $\begin{array}{l}-1.370 \\
(1.367)\end{array}$ \\
\hline & Observations & 929 & 929 & 930 & 927 & 926 & 928 & 952 & 951 \\
\hline (5) & Black & $\begin{array}{c}0.605^{* * * *} \\
(0.116)\end{array}$ & $\begin{array}{l}-0.068 \\
(0.082)\end{array}$ & $\begin{array}{c}0.124 \\
(0.081)\end{array}$ & $\begin{array}{l}-0.100 \\
(0.144)\end{array}$ & $\begin{array}{c}0.092 \\
(0.154)\end{array}$ & $\begin{array}{c}0.092 \\
(0.177)\end{array}$ & $\begin{array}{l}-0.181 \\
(0.366)\end{array}$ & $\begin{array}{l}-2.006^{*} \\
(1.027)\end{array}$ \\
\hline & Observations & 435 & 435 & 435 & 435 & 433 & 434 & 447 & 447 \\
\hline (6) & Hispanic & $\begin{array}{c}0.453^{* * *} \\
(0.059)\end{array}$ & $\begin{array}{l}-0.024 \\
(0.066)\end{array}$ & $\begin{array}{l}-0.032 \\
(0.057)\end{array}$ & $\begin{array}{c}0.058 \\
(0.087)\end{array}$ & $\begin{array}{l}-0.043 \\
(0.086)\end{array}$ & $\begin{array}{c}0.048 \\
(0.126)\end{array}$ & $\begin{array}{l}-0.067 \\
(0.400)\end{array}$ & $\begin{array}{l}-1.109 \\
(0.865)\end{array}$ \\
\hline & Observations & 1,680 & 1,680 & 1,682 & 1,679 & 1,679 & 1,680 & 1,708 & 1,708 \\
\hline (7) & White & $\begin{array}{c}0.289 \\
(0.183)\end{array}$ & $\begin{array}{c}0.015 \\
(0.257)\end{array}$ & $\begin{array}{l}-0.195 \\
(0.221)\end{array}$ & $\begin{array}{c}0.014 \\
(0.277)\end{array}$ & $\begin{array}{c}0.093 \\
(0.375)\end{array}$ & $\begin{array}{l}-0.446 \\
(0.529)\end{array}$ & $\begin{array}{l}-0.151 \\
(0.513)\end{array}$ & $\begin{array}{l}2.301^{*} \\
(1.285)\end{array}$ \\
\hline & Observations & 325 & 325 & 325 & 325 & 325 & 326 & 330 & 329 \\
\hline (8) & Gifted in 5th Grade & $\begin{array}{c}0.368 * * * \\
(0.082)\end{array}$ & $\begin{array}{l}-0.096 \\
(0.102)\end{array}$ & $\begin{array}{c}0.033 \\
(0.095)\end{array}$ & $\begin{array}{c}0.182 \\
(0.124)\end{array}$ & $\begin{array}{c}0.093 \\
(0.159)\end{array}$ & $\begin{array}{c}0.129 \\
(0.230)\end{array}$ & $\begin{array}{c}0.699 \\
(0.558)\end{array}$ & $\begin{array}{l}-2.041 \\
(1.421)\end{array}$ \\
\hline & Observations & 1,003 & 1,003 & 1,005 & 1,004 & 1,003 & 1,004 & 1,017 & 1,016 \\
\hline (9) & Not Gifted in 5th Grade & $\begin{array}{c}0.534^{* * *} \\
(0.071)\end{array}$ & $\begin{array}{l}-0.003 \\
(0.056)\end{array}$ & $\begin{array}{c}-0.005 \\
(0.053)\end{array}$ & $\begin{array}{l}-0.045 \\
(0.077)\end{array}$ & $\begin{array}{l}-0.035 \\
(0.090)\end{array}$ & $\begin{array}{l}-0.027 \\
(0.122)\end{array}$ & $\begin{array}{c}-0.291 \\
(0.288)\end{array}$ & $\begin{array}{l}-0.666 \\
(0.636)\end{array}$ \\
\hline & Observations & 1,570 & 1,570 & 1,570 & 1,567 & 1,567 & 1,569 & 1,604 & 1,604 \\
\hline
\end{tabular}

Achievement is measured in standard deviations of scale scores within grade and year. Disciplinary infractions are the number of infractions warranting a suspension or more severe punishment per year.. Controls for race, gender, economic disadvantage and lagged (5th grade) dependent varable included, along with a linear smoother with a slope shift above the cutoff included. Standard errors are robust to heteroskedasticity and clustered by 7th grade school. Sample is limited to students with Euclidean distances from qualifying via the GT qualification matrix of between -10 and 10 . 
Table 5 - 2SLS Regression Discontinuity Estimates of Impact of Receiving G\&T Services Specification Checks

(1) Quadratic Smoother

Observations

(2) Cubic Smoother

Observations

(3) Add Middle School Fixed Effects

Observations

(4) Limited to Observations With

No Missing Matrix Data

Observations

(6) Distance Between -4 \& 4

Observations

(5) Distance Between -8 \& 8

Observations

(6) Distance Between -12 \& 12

Observations

(6) Distance Between -16 \& 16

Observations

(7) Local Linear Regressions

with Rectangular Kernel

Observations

Bandwidth (from Leave-One-Out

Cross Validation)
Stanford Achievement Test

\begin{tabular}{|c|c|c|c|c|c|c|c|}
\hline \multirow[b]{2}{*}{$\begin{array}{c}\text { First Stage } \\
(1)\end{array}$} & \multicolumn{5}{|c|}{ Achievement Test } & \multirow[b]{2}{*}{$\begin{array}{c}\text { Disciplinary } \\
\text { Infractions } \\
(7) \\
\end{array}$} & \multirow[b]{2}{*}{$\begin{array}{c}\text { Attendance } \\
\text { Rate (\%) } \\
(8)\end{array}$} \\
\hline & $\begin{array}{l}\text { Math } \\
(2)\end{array}$ & $\begin{array}{c}\text { Reading } \\
(3)\end{array}$ & $\begin{array}{c}\text { Language } \\
(4)\end{array}$ & $\begin{array}{c}\text { Social } \\
\text { Science } \\
(5)\end{array}$ & $\begin{array}{c}\text { Science } \\
\text { (6) }\end{array}$ & & \\
\hline $\begin{array}{c}0.424 * * * \\
(0.063)\end{array}$ & $\begin{array}{c}0.120 \\
(0.112)\end{array}$ & $\begin{array}{c}0.007 \\
(0.071)\end{array}$ & $\begin{array}{c}0.246^{* *} \\
(0.111)\end{array}$ & $\begin{array}{c}0.146 \\
(0.135)\end{array}$ & $\begin{array}{l}0.305^{*} \\
(0.159)\end{array}$ & $\begin{array}{l}-0.445 \\
(0.505)\end{array}$ & $\begin{array}{l}-0.565 \\
(1.253)\end{array}$ \\
\hline 2,609 & 2,597 & 2,600 & 2,596 & 2,594 & 2,597 & 2,650 & 2,649 \\
\hline $\begin{array}{c}0.371^{* * *} \\
(0.103)\end{array}$ & $\begin{array}{c}0.057 \\
(0.238)\end{array}$ & $\begin{array}{l}-0.029 \\
(0.157)\end{array}$ & $\begin{array}{c}0.276 \\
(0.203)\end{array}$ & $\begin{array}{l}-0.019 \\
(0.244)\end{array}$ & $\begin{array}{c}0.409 \\
(0.332)\end{array}$ & $\begin{array}{l}-0.617 \\
(0.745)\end{array}$ & $\begin{array}{l}-0.455 \\
(2.036)\end{array}$ \\
\hline 2,609 & 2,597 & 2,600 & 2,596 & 2,594 & 2,597 & 2,650 & 2,649 \\
\hline $\begin{array}{c}0.460 * * * \\
(0.057)\end{array}$ & $\begin{array}{l}-0.014 \\
(0.037)\end{array}$ & $\begin{array}{c}0.007 \\
(0.041)\end{array}$ & $\begin{array}{c}0.041 \\
(0.065)\end{array}$ & $\begin{array}{c}0.009 \\
(0.065)\end{array}$ & $\begin{array}{c}0.023 \\
(0.112)\end{array}$ & $\begin{array}{c}0.067 \\
(0.249)\end{array}$ & $\begin{array}{l}-1.039 * \\
(0.600)\end{array}$ \\
\hline 2,609 & 2,597 & 2,600 & 2,596 & 2,594 & 2,597 & 2,650 & 2,649 \\
\hline $\begin{array}{c}0.456 * * * \\
(0.061)\end{array}$ & $\begin{array}{l}-0.027 \\
(0.048)\end{array}$ & $\begin{array}{c}0.003 \\
(0.044)\end{array}$ & $\begin{array}{c}0.013 \\
(0.067)\end{array}$ & $\begin{array}{l}-0.004 \\
(0.068)\end{array}$ & $\begin{array}{c}0.029 \\
(0.108)\end{array}$ & $\begin{array}{c}0.068 \\
(0.263)\end{array}$ & $\begin{array}{l}-1.186 * \\
(0.684)\end{array}$ \\
\hline 2,538 & 2,526 & 2,528 & 2,525 & 2,522 & 2,525 & 2,577 & 2,576 \\
\hline $\begin{array}{c}0.387 * * * \\
(0.084)\end{array}$ & $\begin{array}{c}0.116 \\
(0.167)\end{array}$ & $\begin{array}{l}-0.097 \\
(0.111)\end{array}$ & $\begin{array}{c}0.132 \\
(0.159)\end{array}$ & $\begin{array}{l}-0.029 \\
(0.170)\end{array}$ & $\begin{array}{c}0.338 \\
(0.246)\end{array}$ & $\begin{array}{c}-0.762 \\
(0.518)\end{array}$ & $\begin{array}{l}-0.835 \\
(1.647)\end{array}$ \\
\hline 849 & 845 & 848 & 845 & 842 & 844 & 860 & 859 \\
\hline $\begin{array}{c}0.462 * * * \\
(0.056)\end{array}$ & $\begin{array}{c}0.005 \\
(0.058)\end{array}$ & $\begin{array}{c}0.014 \\
(0.046)\end{array}$ & $\begin{array}{c}0.111 \\
(0.072)\end{array}$ & $\begin{array}{c}0.056 \\
(0.080)\end{array}$ & $\begin{array}{c}0.115 \\
(0.103)\end{array}$ & $\begin{array}{l}-0.162 \\
(0.325)\end{array}$ & $\begin{array}{l}-0.638 \\
(0.758)\end{array}$ \\
\hline 2,057 & 2,047 & 2,052 & 2,047 & 2,044 & 2,047 & 2,084 & 2,083 \\
\hline $\begin{array}{c}0.472 * * * \\
(0.055)\end{array}$ & $\begin{array}{c}-0.009 \\
(0.039)\end{array}$ & $\begin{array}{c}0.018 \\
(0.036)\end{array}$ & $\begin{array}{l}-0.013 \\
(0.057)\end{array}$ & $\begin{array}{c}0.007 \\
(0.063)\end{array}$ & $\begin{array}{c}0.019 \\
(0.086)\end{array}$ & $\begin{array}{c}0.001 \\
(0.209)\end{array}$ & $\begin{array}{l}-0.823 \\
(0.549)\end{array}$ \\
\hline 3,178 & 3,162 & 3,163 & 3,158 & 3,158 & 3,160 & 3,222 & 3,220 \\
\hline $\begin{array}{c}0.488 * * * \\
(0.055)\end{array}$ & $\begin{array}{c}-0.022 \\
(0.035)\end{array}$ & $\begin{array}{c}0.009 \\
(0.030)\end{array}$ & $\begin{array}{l}-0.015 \\
(0.045)\end{array}$ & $\begin{array}{l}-0.022 \\
(0.061)\end{array}$ & $\begin{array}{c}0.017 \\
(0.077)\end{array}$ & $\begin{array}{c}0.100 \\
(0.179)\end{array}$ & $\begin{array}{l}-0.438 \\
(0.497)\end{array}$ \\
\hline 3,756 & 3,735 & 3,736 & 3,731 & 3,729 & 3,733 & 3,806 & 3,804 \\
\hline - & $\begin{array}{c}0.073 \\
(0.117)\end{array}$ & $\begin{array}{c}0.000 \\
(0.072)\end{array}$ & $\begin{array}{c}0.019 \\
(0.186)\end{array}$ & $\begin{array}{c}0.056 \\
(0.080)\end{array}$ & $\begin{array}{c}0.222 \\
(0.177)\end{array}$ & $\begin{array}{c}1.476 \\
(1.002)\end{array}$ & $\begin{array}{l}-0.434 \\
(1.203)\end{array}$ \\
\hline- & 1,075 & 1,078 & 708 & 2,044 & 1,074 & 429 & 1,092 \\
\hline- & 5 & 5 & 3 & 8 & 5 & 2 & 5 \\
\hline
\end{tabular}

Achievement is measured in standard deviations of scale scores within grade and year. Disciplinary infractions are the number of infractions warranting a suspension or more severe punishment per year. Controls for race, gender, economic disadvantage, LEP, prior gifted status and lagged (5th grade) dependent varable included and a linear smoother with a slope shift above the cutoff except where noted.. Sample is limited to students with Euclidean distances from qualifying via the GT qualification matrix of between -10 and $10 . * * *$, and $* * *$ denote statistical significance at the $10 \%, 5 \%$, and $1 \%$ levels, respectively. Standard errors are robust to heteroskedasticity and clustered by 7 th grade school. 
Table 6 - 2SLS Estimates of Impacts of G\&T Services

Effects on Educational Environment and Student Choices

\begin{tabular}{|c|c|c|c|c|c|c|c|c|c|}
\hline & $\begin{array}{c}\text { Peer Math } \\
\text { Scores in Math } \\
\text { Classes } \\
(1) \\
\end{array}$ & $\begin{array}{l}\text { Peer Reading } \\
\text { Scores in } \\
\text { Read/Eng } \\
\text { Classes } \\
(2) \\
\end{array}$ & $\begin{array}{l}\text { Peer Lang } \\
\text { Scores in } \\
\text { Read/Eng } \\
\text { Classes } \\
(3) \\
\end{array}$ & $\begin{array}{c}\text { Peer Soc } \\
\text { Scores in Soc } \\
\text { Classes } \\
(4) \\
\end{array}$ & $\begin{array}{c}\text { Peer Science } \\
\text { Scores in } \\
\text { Science Classes } \\
(5) \\
\end{array}$ & $\begin{array}{c}\text { \# of Core } \\
\text { Regular Classes } \\
(6) \\
\end{array}$ & $\begin{array}{l}\text { \# of Core } \\
\text { Vanguard } \\
\text { Classes } \\
(7) \\
\end{array}$ & $\begin{array}{c}\text { Enrolled in } \\
\text { Vanguard Math } \\
(8) \\
\end{array}$ & $\begin{array}{l}\text { Enrolled in } \\
\text { Vanguard } \\
\text { English } \\
\text { (9) } \\
\end{array}$ \\
\hline Enrolled in GT & $\begin{array}{c}0.348 * * \\
(0.166)\end{array}$ & $\begin{array}{c}0.287^{*} \\
(0.156)\end{array}$ & $\begin{array}{c}0.311^{* *} \\
(0.146)\end{array}$ & $\begin{array}{l}0.235^{*} \\
(0.132)\end{array}$ & $\begin{array}{l}0.272 * \\
(0.150)\end{array}$ & $\begin{array}{c}-0.014 \\
(0.267)\end{array}$ & $\begin{array}{l}1.145^{*} \\
(0.624)\end{array}$ & $\begin{array}{l}0.315^{*} \\
(0.158)\end{array}$ & $\begin{array}{c}0.241 \\
(0.171)\end{array}$ \\
\hline \multirow[t]{2}{*}{ Observations } & 2,629 & 2,494 & 2,494 & 2,567 & 2,567 & 2,643 & 2,643 & 2,629 & 2,497 \\
\hline & $\begin{array}{c}\text { Enrolled in } \\
\text { Vanguard } \\
\text { Social Science } \\
(10) \\
\end{array}$ & $\begin{array}{l}\text { Enrolled in } \\
\text { Vanguard } \\
\text { Science } \\
\text { (11) }\end{array}$ & $\begin{array}{c}\text { Attends Zoned } \\
\text { School } \\
(12) \\
\end{array}$ & $\begin{array}{c}\text { Attends Non- } \\
\text { Zoned GT } \\
\text { Magnet Campus } \\
\text { (13) } \\
\end{array}$ & $\begin{array}{c}\text { Attends Other } \\
\text { Non-Zoned } \\
(14) \\
\end{array}$ & $\begin{array}{c}\text { Math Teacher } \\
\text { Fixed Effect } \\
(15) \\
\end{array}$ & $\begin{array}{c}\text { Read/Eng } \\
\text { Teacher Fixed } \\
\text { Effect } \\
(16) \\
\end{array}$ & $\begin{array}{c}\text { Science Teacher } \\
\text { Fixed Effect } \\
(17) \\
\end{array}$ & $\begin{array}{c}\text { Social Science } \\
\text { Teacher Fixed } \\
\text { Effect } \\
(18) \\
\end{array}$ \\
\hline Enrolled in GT & $\begin{array}{l}0.282 * \\
(0.165)\end{array}$ & $\begin{array}{c}0.282 * \\
(0.165)\end{array}$ & $\begin{array}{c}-0.050 \\
(0.109)\end{array}$ & $\begin{array}{c}0.260 * * \\
(0.109)\end{array}$ & $\begin{array}{c}-0.210^{* *} \\
(0.098)\end{array}$ & $\begin{array}{c}-0.001 \\
(0.025)\end{array}$ & $\begin{array}{c}0.016 \\
(0.010)\end{array}$ & $\begin{array}{c}0.005 \\
(0.014)\end{array}$ & $\begin{array}{c}0.014 \\
(0.013)\end{array}$ \\
\hline Observations & 2,567 & 2,567 & 2,623 & 2,623 & 2,623 & 2,650 & 2,621 & 2,621 & 2,621 \\
\hline
\end{tabular}

Achievement is measured in standard deviations of scale scores within grade and year. Teacher fixed effects are estimates from a student-level regression of achievement on lagged achievement, peer lagged achievement, race, gender, special education, LEP, at-risk status, teacher fixed-effects and school fixed-effects. Controls for race, gender, economic disadvantage, LEP, prior gifted status and lagged (5th grade) dependent varable included. Also includes a linear smoother with a slope shift above the cutoff. Peers

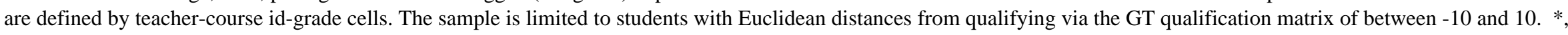
$* *$, and $* * *$ denote statistical significance at the $10 \%, 5 \%$, and $1 \%$ levels, respectively. Standard errors are robust to heteroskedasticity and clustered by 7 th grade school. 
Table 7 - Balancing Tests for GT Magnet Lotteries - Covariates Measured in 5th Grade

\begin{tabular}{|c|c|c|c|c|c|c|c|c|c|c|}
\hline Sample & $\begin{array}{c}\text { Asian } \\
(1) \\
\end{array}$ & $\begin{array}{c}\text { Black } \\
(2) \\
\end{array}$ & $\begin{array}{c}\text { Hispanic } \\
\text { (3) }\end{array}$ & $\begin{array}{l}\text { White } \\
(4)\end{array}$ & $\begin{array}{c}\text { Econ Disadv } \\
(5) \\
\end{array}$ & $\begin{array}{c}\text { Female } \\
(6)\end{array}$ & $\begin{array}{c}\text { At-Risk } \\
(7)\end{array}$ & $\begin{array}{c}\text { Special } \\
\text { Education } \\
(8) \\
\end{array}$ & $\begin{array}{l}\text { LEP } \\
(9) \\
\end{array}$ & $\begin{array}{c}\text { Gifted } \\
(10) \\
\end{array}$ \\
\hline $\begin{array}{l}\text { Ex-Ante - Baseline } \\
\text { Lottery }\end{array}$ & $\begin{array}{l}-0.030 \\
(0.044)\end{array}$ & $\begin{array}{c}0.030 \\
(0.038)\end{array}$ & $\begin{array}{c}0.041 \\
(0.044)\end{array}$ & $\begin{array}{l}-0.041 \\
(0.050)\end{array}$ & $\begin{array}{l}-0.035 \\
(0.045)\end{array}$ & $\begin{array}{l}-0.006 \\
(0.047)\end{array}$ & $\begin{array}{l}-0.011 \\
(0.010)\end{array}$ & $\begin{array}{l}-0.019 \\
(0.017)\end{array}$ & $\begin{array}{l}-0.033 \\
(0.022)\end{array}$ & $\begin{array}{l}-0.028 \\
(0.035)\end{array}$ \\
\hline Observations & 542 & 542 & 542 & 542 & 542 & 542 & 542 & 542 & 542 & 542 \\
\hline $\begin{array}{l}\text { Ex-Post - Estimation } \\
\text { Sample }\end{array}$ & $\begin{array}{l}-0.027 \\
(0.048)\end{array}$ & $\begin{array}{c}0.041 \\
(0.038)\end{array}$ & $\begin{array}{c}0.042 \\
(0.055)\end{array}$ & $\begin{array}{l}-0.057 \\
(0.056)\end{array}$ & $\begin{array}{l}-0.050 \\
(0.059)\end{array}$ & $\begin{array}{l}-0.001 \\
(0.052)\end{array}$ & $\begin{array}{l}-0.009 \\
(0.011)\end{array}$ & $\begin{array}{l}-0.015 \\
(0.023)\end{array}$ & $\begin{array}{l}-0.031 \\
(0.027)\end{array}$ & $\begin{array}{l}-0.024 \\
(0.047)\end{array}$ \\
\hline Observations & 437 & 437 & 437 & 437 & 437 & 437 & 437 & 437 & 437 & 437 \\
\hline \multicolumn{8}{|c|}{ Stanford Achievement Test } & \multirow[b]{2}{*}{$\begin{array}{c}\text { Attendance } \\
\text { Rate } \\
(18) \\
\end{array}$} & & \multirow[b]{2}{*}{$\begin{array}{c}\text { Teacher } \\
\text { Score } \\
(20) \\
\end{array}$} \\
\hline Sample & $\begin{array}{l}\text { GT Magnet } \\
(11) \\
\end{array}$ & $\begin{array}{c}\text { Total Matrix } \\
\text { Points } \\
(12) \\
\end{array}$ & $\begin{array}{l}\text { Math } \\
(13)\end{array}$ & $\begin{array}{c}\text { Reading } \\
(14)\end{array}$ & $\begin{array}{c}\text { Language } \\
(15)\end{array}$ & $\begin{array}{l}\text { Social Studies } \\
(16) \\
\end{array}$ & $\begin{array}{c}\text { Science } \\
(17)\end{array}$ & & $\begin{array}{c}\text { Infractions } \\
(19) \\
\end{array}$ & \\
\hline $\begin{array}{l}\text { Ex-Ante - Baseline } \\
\text { Lottery }\end{array}$ & $\begin{array}{c}0.035 \\
(0.030)\end{array}$ & $\begin{array}{c}0.243 \\
(0.926)\end{array}$ & $\begin{array}{c}0.027 \\
(0.069)\end{array}$ & $\begin{array}{c}0.073 \\
(0.063)\end{array}$ & $\begin{array}{l}-0.034 \\
(0.077)\end{array}$ & $\begin{array}{c}0.053 \\
(0.089)\end{array}$ & $\begin{array}{c}0.010 \\
(0.076)\end{array}$ & $\begin{array}{l}-0.180 \\
(0.201)\end{array}$ & $\begin{array}{l}-0.022 \\
(0.021)\end{array}$ & $\begin{array}{c}0.029 \\
(1.304)\end{array}$ \\
\hline Observations & 542 & 542 & 540 & 541 & 539 & 540 & 539 & 542 & 542 & 536 \\
\hline $\begin{array}{l}\text { Ex-Post - Estimation } \\
\text { Sample }\end{array}$ & $\begin{array}{c}0.055 \\
(0.045)\end{array}$ & $\begin{array}{c}0.909 \\
(1.173)\end{array}$ & $\begin{array}{l}0.128^{*} \\
(0.074)\end{array}$ & $\begin{array}{c}0.100 \\
(0.075)\end{array}$ & $\begin{array}{l}-0.059 \\
(0.077)\end{array}$ & $\begin{array}{c}0.063 \\
(0.096)\end{array}$ & $\begin{array}{c}0.090 \\
(0.088)\end{array}$ & $\begin{array}{l}-0.064 \\
(0.230)\end{array}$ & $\begin{array}{l}-0.022 \\
(0.025)\end{array}$ & $\begin{array}{c}-1.005 \\
(1.471)\end{array}$ \\
\hline Observations & 437 & 437 & 437 & 437 & 436 & 437 & 436 & 437 & 437 & 434 \\
\hline
\end{tabular}

Achievement is measured in standard deviations of scale scores within grade and year. Disciplinary infractions are the number of infractions warranting a suspension or more severe punishment per year. Lotteries for two schools were conducted in 2007-08 hence regresions include indicators for lottery fixed effects. Coefficients are for an indicator for whether the student won the lottery. Robust standard errors clustered by 5th grade school in parentheses. Results without clustering are similar and provided in the online appendix. 
Table 8 - Effect of Attending a GT Magnet School Relative to a GT Neighborhood Program

\begin{tabular}{|c|c|c|c|c|c|c|c|}
\hline \multirow{2}{*}{\multicolumn{2}{|c|}{ Model }} & \multicolumn{5}{|c|}{ Stanford Achievement Test } & \multirow{2}{*}{$\begin{array}{c}\text { Attendence Rate } \\
\qquad(\%) \\
(6)\end{array}$} \\
\hline & & $\begin{array}{c}\text { Math } \\
(1)\end{array}$ & $\begin{array}{c}\text { Reading } \\
(2)\end{array}$ & $\begin{array}{c}\text { Language } \\
\text { (3) }\end{array}$ & $\begin{array}{c}\text { Social Studies } \\
(4)\end{array}$ & $\begin{array}{c}\text { Science } \\
\text { (5) }\end{array}$ & \\
\hline \multirow[t]{2}{*}{ (1) } & 2SLS - Unweighted, No Controls & $\begin{array}{c}0.042 \\
(0.178)\end{array}$ & $\begin{array}{c}0.023 \\
(0.103)\end{array}$ & $\begin{array}{c}0.102 \\
(0.065)\end{array}$ & $\begin{array}{c}0.039 \\
(0.083)\end{array}$ & $\begin{array}{c}0.249 * * \\
(0.114)\end{array}$ & $\begin{array}{l}-0.434 \\
(0.636)\end{array}$ \\
\hline & Observations & 437 & 438 & 436 & 437 & 437 & 440 \\
\hline \multirow[t]{2}{*}{ (2) } & 2SLS - Unweighted, Controls & $\begin{array}{l}-0.100 \\
(0.112)\end{array}$ & $\begin{array}{l}-0.058 \\
(0.105)\end{array}$ & $\begin{array}{l}0.142 * \\
(0.081)\end{array}$ & $\begin{array}{l}-0.032 \\
(0.098)\end{array}$ & $\begin{array}{l}0.208 * \\
(0.119)\end{array}$ & $\begin{array}{l}-0.425 \\
(0.411)\end{array}$ \\
\hline & Observations & 437 & 438 & 435 & 437 & 436 & 440 \\
\hline \multirow[t]{2}{*}{ (3) } & 2SLS - Weighted, No Controls & $\begin{array}{l}-0.266 \\
(0.291)\end{array}$ & $\begin{array}{l}-0.130 \\
(0.221)\end{array}$ & $\begin{array}{l}-0.060 \\
(0.148)\end{array}$ & $\begin{array}{l}-0.120 \\
(0.214)\end{array}$ & $\begin{array}{c}0.243 \\
(0.201)\end{array}$ & $\begin{array}{c}0.043 \\
(1.996)\end{array}$ \\
\hline & Observations & 436 & 437 & 435 & 436 & 436 & 439 \\
\hline \multirow[t]{2}{*}{ (4) } & 2SLS - Weighted, Controls & $\begin{array}{l}-0.224 \\
(0.171)\end{array}$ & $\begin{array}{l}-0.018 \\
(0.172)\end{array}$ & $\begin{array}{c}0.001 \\
(0.114)\end{array}$ & $\begin{array}{l}-0.036 \\
(0.136)\end{array}$ & $\begin{array}{c}0.281^{* *} \\
(0.130)\end{array}$ & $\begin{array}{c}0.364 \\
(1.489)\end{array}$ \\
\hline & Observations & 436 & 437 & 435 & 436 & 436 & 439 \\
\hline \multirow[t]{2}{*}{ (5) } & $\begin{array}{l}\text { Engberg, Epple, Imbrogno, Sieg, Zimmer } \\
\text { (2011) Bounds - Upper Bound }\end{array}$ & $\begin{array}{l}-0.019 \\
(0.196)\end{array}$ & $\begin{array}{l}-0.095 \\
(0.157)\end{array}$ & $\begin{array}{c}0.074 \\
(0.162)\end{array}$ & $\begin{array}{l}-0.064 \\
(0.185)\end{array}$ & $\begin{array}{l}0.344^{*} \\
(0.180)\end{array}$ & - \\
\hline & Observations & 437 & 438 & 436 & 437 & 437 & - \\
\hline \multirow[t]{2}{*}{ (6) } & $\begin{array}{l}\text { Engberg, Epple, Imbrogno, Sieg, Zimmer } \\
\text { (2011) Bounds - Lower Bound }\end{array}$ & $\begin{array}{l}-0.353 \\
(0.251)\end{array}$ & $\begin{array}{l}-0.310 \\
(0.192)\end{array}$ & $\begin{array}{l}-0.207 \\
(0.215)\end{array}$ & $\begin{array}{l}-0.389 \\
(0.249)\end{array}$ & $\begin{array}{l}-0.013 \\
(0.248)\end{array}$ & - \\
\hline & Observations & 437 & 438 & 436 & 437 & 437 & - \\
\hline
\end{tabular}

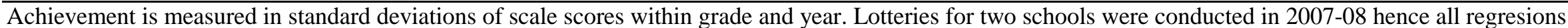
include indicators for lottery fixed effects. Coefficients are for an indicator for whether the student is enrolled in a GT magnet program in 7th grade. Robust standard errors clustered by 7th grade school in parentheses. Results without clustering are similar and provided in the online appendix. Controls include indicators during 5th grade for race, gender, special education, LEP, at-risk status, gifted, whether the student was enrolled in a GT magnet, and a lagged dependent variable. Weighted regressions are weighted by the inverse of the estimated probability of remaining in the data. See text for details. In order to avoid slow convergence due to a very small portion of the sample being in special education or LEP, we drop those controls from the bounding analysis.

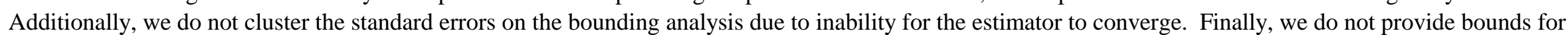
attendance due to poor performance with censored data. See paper for details. 
Table 9 - Treatments from Attending a GT Magnet School Relative to a GT Neighborhood Program

\begin{tabular}{|c|c|c|c|c|c|c|c|c|c|}
\hline \multirow[t]{2}{*}{ Model } & \multicolumn{5}{|c|}{ Mean Peer Achievement (Std Deviations) } & \multicolumn{4}{|c|}{ Teacher Fixed Effects } \\
\hline & $\begin{array}{c}\text { Math in } \\
\text { Math Class } \\
(1) \\
\end{array}$ & $\begin{array}{l}\text { Reading in } \\
\text { English } \\
\text { Class } \\
(2) \\
\end{array}$ & $\begin{array}{c}\text { Language in } \\
\text { English } \\
\text { Class } \\
(3) \\
\end{array}$ & $\begin{array}{c}\text { Social } \\
\text { Studies in } \\
\text { Soc Class } \\
(4) \\
\end{array}$ & $\begin{array}{c}\text { Science in } \\
\text { Science } \\
\text { Class } \\
(5) \\
\end{array}$ & $\begin{array}{c}\text { Math } \\
\text { (6) } \\
\end{array}$ & $\begin{array}{c}\text { English/ } \\
\text { Reading } \\
(7) \\
\end{array}$ & $\begin{array}{c}\text { Social } \\
\text { Studies } \\
(8) \\
\end{array}$ & $\begin{array}{c}\text { Science } \\
\text { (9) }\end{array}$ \\
\hline 2SLS - Unweighted, Controls & $\begin{array}{c}1.066^{* * *} \\
(0.145)\end{array}$ & $\begin{array}{c}0.659 * * * \\
(0.149)\end{array}$ & $\begin{array}{c}0.579 * * * \\
(0.120)\end{array}$ & $\begin{array}{c}0.794^{* * *} \\
(0.123)\end{array}$ & $\begin{array}{c}0.524^{* * *} \\
(0.122)\end{array}$ & $\begin{array}{c}0.081^{* * *} \\
(0.015)\end{array}$ & $\begin{array}{c}0.032^{* *} \\
(0.013)\end{array}$ & $\begin{array}{c}0.031^{*} \\
(0.017)\end{array}$ & $\begin{array}{c}0.017 \\
(0.014)\end{array}$ \\
\hline Observations & 440 & 436 & 436 & 439 & 439 & 440 & 440 & 440 & 440 \\
\hline 2SLS - Weighted, Controls & $\begin{array}{c}1.164^{* * *} \\
(0.179)\end{array}$ & $\begin{array}{c}0.751^{* * * *} \\
(0.172)\end{array}$ & $\begin{array}{c}0.686^{* * *} \\
(0.143)\end{array}$ & $\begin{array}{c}0.952^{* * *} \\
(0.180)\end{array}$ & $\begin{array}{c}0.659 * * * \\
(0.166)\end{array}$ & $\begin{array}{c}0.085^{* * * *} \\
(0.019)\end{array}$ & $\begin{array}{c}0.032 * * * \\
(0.011)\end{array}$ & $\begin{array}{c}0.041^{* *} \\
(0.019)\end{array}$ & $\begin{array}{c}0.016 \\
(0.013)\end{array}$ \\
\hline Observations & 439 & 435 & 435 & 438 & 438 & 439 & 439 & 439 & 439 \\
\hline
\end{tabular}

Achievement is measured in standard deviations of scale scores within grade and year. Teacher fixed effects are estimates from a student-level regression of achievement on lagged achievement, peer lagged achievement, race, gender, special education, LEP, at-risk status, teacher fixed-effects and school fixedeffects. Lotteries for two schools were conducted in 2007-08 hence all regresions include indicators for lottery fixed effects. Coefficients are for an indicator for whether the student is enrolled in a GT magnet program in 7th grade. Peers are defined by teacher-course id-grade cells. Robust standard errors clustered by 7th grade school in parentheses. Results without clustering are similar and provided in the online appendix. Weighted regressions are weighted by the inverse of the estimated probability of remaining in the data. See text for details. Controls include indicators during 5th grade for race, gender, special education, LEP, at-risk status, gifted, whether the student was enrolled in a GT magnet, and a lagged dependent variable. *, **, and *** denote statistical significance at the $10 \%, 5 \%$, and $1 \%$ levels, respectively. 
Table 10 - 2SLS Estimates of Impacts of G\&T on Course Grades and Rank (2007-08 Evaluation Cohort)

\begin{tabular}{|c|c|c|c|c|c|c|c|c|}
\hline & \multicolumn{4}{|c|}{ I. Course Grades } & \multicolumn{4}{|c|}{ II. Rank in Course (Percentiles) } \\
\hline & $\begin{array}{c}\text { Math } \\
(1)\end{array}$ & $\begin{array}{c}\text { English } \\
(2)\end{array}$ & $\begin{array}{c}\text { Social Studies } \\
\text { (3) } \\
\end{array}$ & $\begin{array}{c}\text { Science } \\
(4)\end{array}$ & $\begin{array}{c}\text { Math } \\
(5)\end{array}$ & $\begin{array}{c}\text { English } \\
(6) \\
\end{array}$ & $\begin{array}{c}\text { Social Studies } \\
(7) \\
\end{array}$ & $\begin{array}{c}\text { Science } \\
(8)\end{array}$ \\
\hline & \multicolumn{8}{|c|}{ A. Regression Discontinuity Analysis } \\
\hline & \multicolumn{8}{|c|}{ i. 7th Grade } \\
\hline Enrolled in GT & $\begin{array}{c}-4.142 * * \\
(1.616)\end{array}$ & $\begin{array}{l}-2.621 \\
(1.744)\end{array}$ & $\begin{array}{l}-2.473 \\
(1.645)\end{array}$ & $\begin{array}{l}-1.501 \\
(1.052)\end{array}$ & $\begin{array}{c}-21.1^{* * * *} \\
(6.9)\end{array}$ & $\begin{array}{c}-15.5^{* *} \\
(7.1)\end{array}$ & $\begin{array}{c}-17.1^{* * * *} \\
(5.8)\end{array}$ & $\begin{array}{c}-13.2^{* *} \\
(6.0)\end{array}$ \\
\hline \multirow[t]{2}{*}{ Observations } & 2,643 & 2,510 & 2,581 & 2,602 & 2,643 & 2,510 & 2,581 & 2,602 \\
\hline & \multicolumn{8}{|c|}{ ii. 6th Grade } \\
\hline Enrolled in GT & $\begin{array}{c}-3.422 * * * \\
(1.179)\end{array}$ & $\begin{array}{l}-1.953 \\
(1.491)\end{array}$ & $\begin{array}{l}-2.931 * * \\
(1.355)\end{array}$ & $\begin{array}{c}-3.411^{* *} \\
(1.442)\end{array}$ & $\begin{array}{c}-17.9 * * * \\
(6.2)\end{array}$ & $\begin{array}{c}-16.9 * * * \\
(6.5)\end{array}$ & $\begin{array}{c}-22.6 * * * \\
(7.0)\end{array}$ & $\begin{array}{c}-22.9 * * * \\
(6.9)\end{array}$ \\
\hline \multirow[t]{2}{*}{ Observations } & 2,739 & 2,609 & 2,754 & 2,733 & 2,739 & 2,609 & 2,754 & 2,733 \\
\hline & \multicolumn{8}{|c|}{ B. Lottery Analysis (7th Grade) } \\
\hline $\begin{array}{l}\text { Unweighted, } \\
\text { Controls }\end{array}$ & $\begin{array}{c}-8.283 * * * \\
(1.660)\end{array}$ & $\begin{array}{c}-4.096 * * \\
(1.561)\end{array}$ & $\begin{array}{c}-4.062^{* *} \\
(1.654)\end{array}$ & $\begin{array}{c}-6.988 * * * \\
(1.309)\end{array}$ & $\begin{array}{c}-29.5^{* * * *} \\
(4.8)\end{array}$ & $\begin{array}{c}-27.1^{* * *} \\
(5.0)\end{array}$ & $\begin{array}{c}-27.8^{* * *} \\
(6.5)\end{array}$ & $\begin{array}{c}-29.3^{* * *} \\
(6.3)\end{array}$ \\
\hline Observations & 440 & 437 & 439 & 439 & 440 & 437 & 439 & 439 \\
\hline $\begin{array}{l}\text { Weighted, } \\
\text { Controls }\end{array}$ & $\begin{array}{c}-7.311^{* * *} \\
(1.847)\end{array}$ & $\begin{array}{l}-2.719 \\
(1.990)\end{array}$ & $\begin{array}{c}-4.733 * * \\
(1.733)\end{array}$ & $\begin{array}{c}-8.121^{* * *} \\
(2.297)\end{array}$ & $\begin{array}{c}-30.7^{* * * *} \\
(5.4)\end{array}$ & $\begin{array}{c}-30.4^{* * *} \\
(7.7)\end{array}$ & $\begin{array}{c}-33.8 * * * \\
(6.8)\end{array}$ & $\begin{array}{c}-36.1^{* * *} \\
(8.9)\end{array}$ \\
\hline Observations & 439 & 436 & 438 & 438 & 439 & 436 & 438 & 438 \\
\hline
\end{tabular}

Rank is determined by rank-ordering the final grade in each course within school, grade and year, converted to percentiles. RD: Controls for race, gender, economic disadvantage, LEP, and prior gifted status are included along with a linear smoother with a slope shift above the cutoff. Sample is limited to students with Euclidean distances from qualifying via the GT qualification matrix of between -10 and 10. Standard errors are robust to heteroskedasticity and clustered by 7th grade school. Lottery: Lotteries for two schools were conducted in 2007-08 hence all regresions include indicators for lottery fixed effects. Coefficients are for an indicator for whether the student is enrolled in a GT magnet program in 7th grade. Peers are defined by teacher-course id-grade cells. Robust standard errors clustered by 7th grade school in parentheses. Results without clustering are similar and provided in the online appendix. Weighted regressions are weighted by the inverse of the estimated probability of remaining in the data. See text for details. Controls include indicators during 5th grade for race, gender, special education, LEP, at-risk status, gifted, and whether the student was enrolled in a GT magnet. *, **, and $* * *$ denote statistical significance at the $10 \%$, $5 \%$, and $1 \%$ levels, respectively. 